\title{
Structural studies on inclusion compounds and solvent sorption behavior of gradually elongated wheel-and-axle-type diol hosts featuring lateral benzo[ $[b]$ thiophene units
}

\author{
Felix Katzsch $^{\mathrm{a}}$, Tobias Gruber ${ }^{\mathrm{b}, *}$, Edwin Weber ${ }^{\mathrm{a}, *}$ \\ ${ }^{a}$ Institut für Organische Chemie, TU Bergakademie Freiberg, Leipziger Straße 29, 09596 \\ Freiberg/Sachsen, Germany. \\ ${ }^{b}$ School of Pharmacy, University of Lincoln, Joseph Banks Laboratories, Green Lane, \\ Lincoln, Lincolnshire, LN6 7DL, United Kingdom. \\ * Corresponding authors. Tel: +44 (0)1522 837396 (T. Gruber); Tel: +49 (0)3731 39 2386, \\ Fax: +49 (0)3731 393170 (E. Weber) \\ E -mail addresses. tgruber@lincoln.ac.uk (T. Gruber); edwin.weber@chemie.tu-freiberg.de \\ (E. Weber).
}




\section{HIGHLIGHTS}

- The syntheses of gradually elongated wheel-and-axle-type hosts are presented.

- A longer central spacer unit does not improve the general inclusion behaviour.

- Most efficient solvent inclusion in the crystal is found for a biphenyl spacer.

- The ratio of vapor absorption is notably high for the $\mathrm{C} \equiv \mathrm{C}-\mathrm{Ph}-\mathrm{C} \equiv \mathrm{C}$ spacer.

- A structure memory effect has been shown.

Keywords:

Diol hosts

Crystalline inclusion compounds

X-ray structural study

Quartz crystal microbalance

Vapor absorption measurement 


\begin{abstract}
Based on the wheel-and-axle design strategy, a series of six new clathrate hosts featuring two $\operatorname{di}($ benzo $[b]$ thien-2-yl)hydroxymethyl units attached to both ends of a central linear building element of varying length have been synthesized and their capability to form crystalline inclusion compounds with a fixed range of organic solvents are reported. X-ray crystal structures of relevant inclusion compounds have been determined and are comparatively discussed involving structural modification of the host molecules. Organic vapor sorption behavior of the host compounds coated as solid films on the quartz crystal of a QCM device has been studied. Significant differences in the affinities towards solvent vapors dependent both on structural and polarity properties of host and solvent are observed, indicating potential application as mass sensitive materials.
\end{abstract}




\section{Introduction}

Aiming at applications such as separation, sensing and storage of chemical substances, crystalline inclusion compounds are very encouraging [1-4]. In previous studies concerning this topic respective results are evident. This applies particularly for the inclusions formed of hosts derived from and 'wheel-and-axle' strategy $[5,6]$. As defined by this strategy, conventional host compounds feature a structure having two bulky diarylhydroxymethyl moieties attached to a central linear building element mostly composed of ethynylene, 1,4-phenylene, 4,4'biphenylene or combinations of these structural units involving varied expansions of the rigid central axis. Owing to their irregular shape, corresponding hosts do not pack efficiently and thus they tend to yield inclusion compounds in the presence of neutral guest molecules. In a modification of this proven design, wheel-and-axle type geometries have also been created bipartitely via an association of bulky carboxylic acid fragments [7] or using ligands of varying length for bridging the metal centers of porphyrins [8,9] or other metal containing molecules [10]. Hence, it is convincingly shown that the covalently linked axis of a conventional wheeland-axle host molecule can be replaced by a system of hydrogen bonds or by coordination of ligands generating inclusions alike. Moreover, derived from the existing findings, the length of the central axis is demonstrated to decisively control the void dimensions as well as the mode of aggregation in the crystal including, e.g., wheel-and-axle or shish-kebab type shapes of supramolecular scaffolds [8,9], aside from the kind of subunits that compose the molecular wheels exercising a similar effect. Only recently, steroidal wheel-and-axle-type hosts [11] as well as the exchange of the lateral aryl groups of respective host molecules against heterocycles [12] opened up a further new way of structural modification, showing high potential to control inclusion selectivity of organic guest species. This has been confirmed by the host molecules BTh1 and BTh2 (Fig. 1) bearing di(benzo[b]thien-2-yl)hydroxymethyl moieties laterally attached to central ethynylene and 1,4-phenylene units, respectively [13]. For obvious reasons, an extension of the central axis both of BTh1 and BTh2 by the insertion of additional ethynylene and 1,4-phenylene units or substitution of a trigonal benzene-1,3,5-triyl moiety for the linear 1,4-phenylene building element of BTh2 in order to increase the number of the lateral bulky functional groups seemed very promising, giving rise to compounds 1-5 and compound 6, respectively (Fig. 1) Hence, all these compounds being distinguished by a gradually increased linear or geometrically modified structure were synthesized and comparatively studied with reference to the formation of crystalline host-guest inclusion behaviour of the prototype hosts BTh1 and BTh2 towards organic guests. Moreover, no less than seven crystal structures of 
solvent inclusions formed of $1(\mathbf{1 a}), 2(\mathbf{2 a}, \mathbf{2 b}), \mathbf{4}(\mathbf{4 a}-\mathbf{4 c})$ and $\mathbf{5}(\mathbf{5 a})$, that have been isolated, are described giving detailed information of the molecular conformations as well as the supramolecular organization and interactions between host and guest in the solid state. Finally, compounds 1-6 have been tested as solid coatings of a quartz crystal microbalance (QCM) [14] to reveal their potential in organic vapor sorption and conclusions are drawn from all the findings.

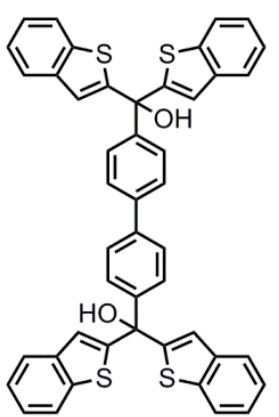

1

$\mathbf{1} \mathbf{a}=\mathbf{1} \cdot$ pyridine $(1: 2) \quad \mathbf{2 a}=\mathbf{2} \cdot$ pyridine $(1: 5)$ $\mathbf{2 b}=\mathbf{2} \cdot n-\mathrm{BuOH}(1: 2)$

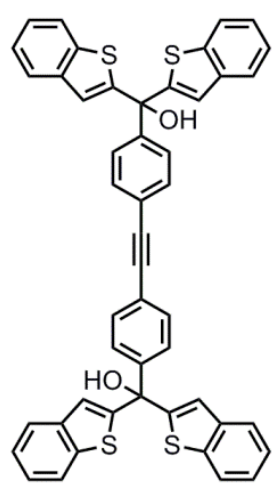

3

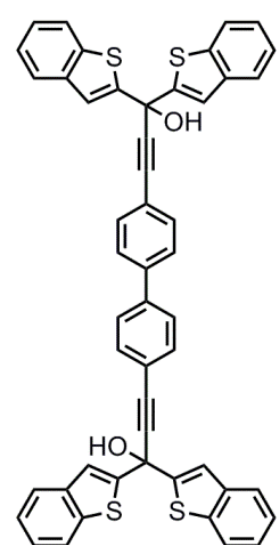

4

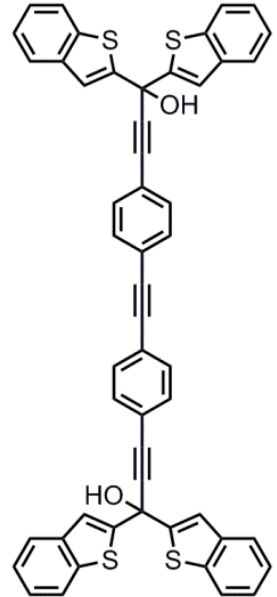

5

$\mathbf{4 a}=\mathbf{4} \cdot$ pyridine $(1: 3)$ $\mathbf{4 b}=\mathbf{4} \cdot$ acetone $(1: 1)$ $\mathbf{4 c}=\mathbf{4} \cdot \operatorname{THF}(1: 4)$

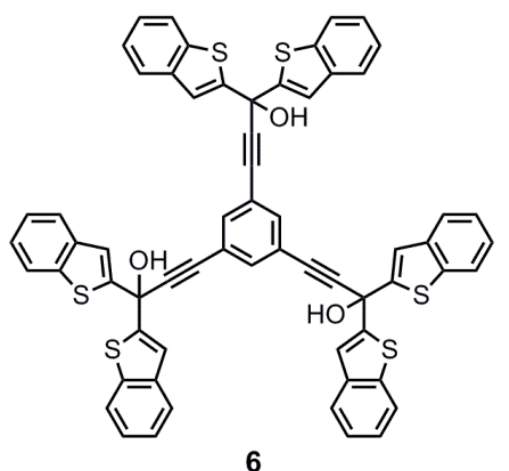

6

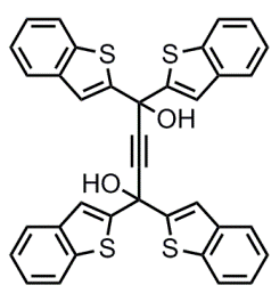

BTh1

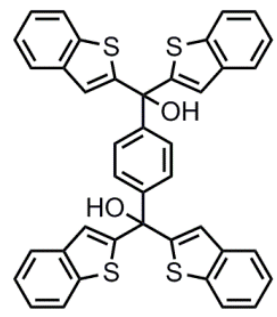

BTh2

Fig. 1. Chemical formulae of the studied diol host compounds 1-6 including compounds for comparison (BTh1 and BTh2) and specification of corresponding inclusion compounds proven by X-ray structure determination.

\section{Results and discussion}

Preparation of compounds

Syntheses of the host compounds 1-6 were performed as illustrated in Fig. $2(\mathbf{1}, \mathbf{3}, \mathbf{6})$ and Fig. $3(\mathbf{2}, \mathbf{4}, \mathbf{5})$. For the preparation of $\mathbf{1}$, this involves reaction of dimethyl biphenyl-4,4'- 
dicarboxylate (7) with in situ generated 2-lithiobenzo[b]thiophene (obtained from benzo $[b]$ thiophene 8 and $n$-butyl lithium in dry THF at $-30{ }^{\circ} \mathrm{C}$ under argon). Analogous reaction protocols using dimethyl 4,4'-(ethynylene)dibenzoate (9) or trimethyl 3,3',3"-(benzene-1,3,5triyl)tripropynoate (11) (prepared from 10) as ester components yielded $\mathbf{3}$ and $\mathbf{6}$, respectively. Differing from the literature description [15], the dimethyl dicarboxylate 7 was prepared from 4-(methoxycarbonyl)phenylboronic acid (synthesized by literature procedures $[16,17]$ ) and methyl 4-iodobenzoate in the presence of $\mathrm{Pd}\left(\mathrm{PPh}_{3}\right)_{2} \mathrm{Cl}_{2}$ and $\mathrm{NaHCO}_{3}$ in water/THF following a Suzuki-Miyaura type reaction [18]. The dimethyl dicarboxylate 9 was obtained from methyl 4-ethynylbenzoate and methyl 4-iodobenzoate using a described Sonogashira-Hagihara coupling method [19]. The triester 11, not yet being mentioned in the literature before, was synthesized from 1,3,5-triethynylbenzene (10) [20] and methyl chloroformiate on treatment with $n$-butyl lithium in dry THF.
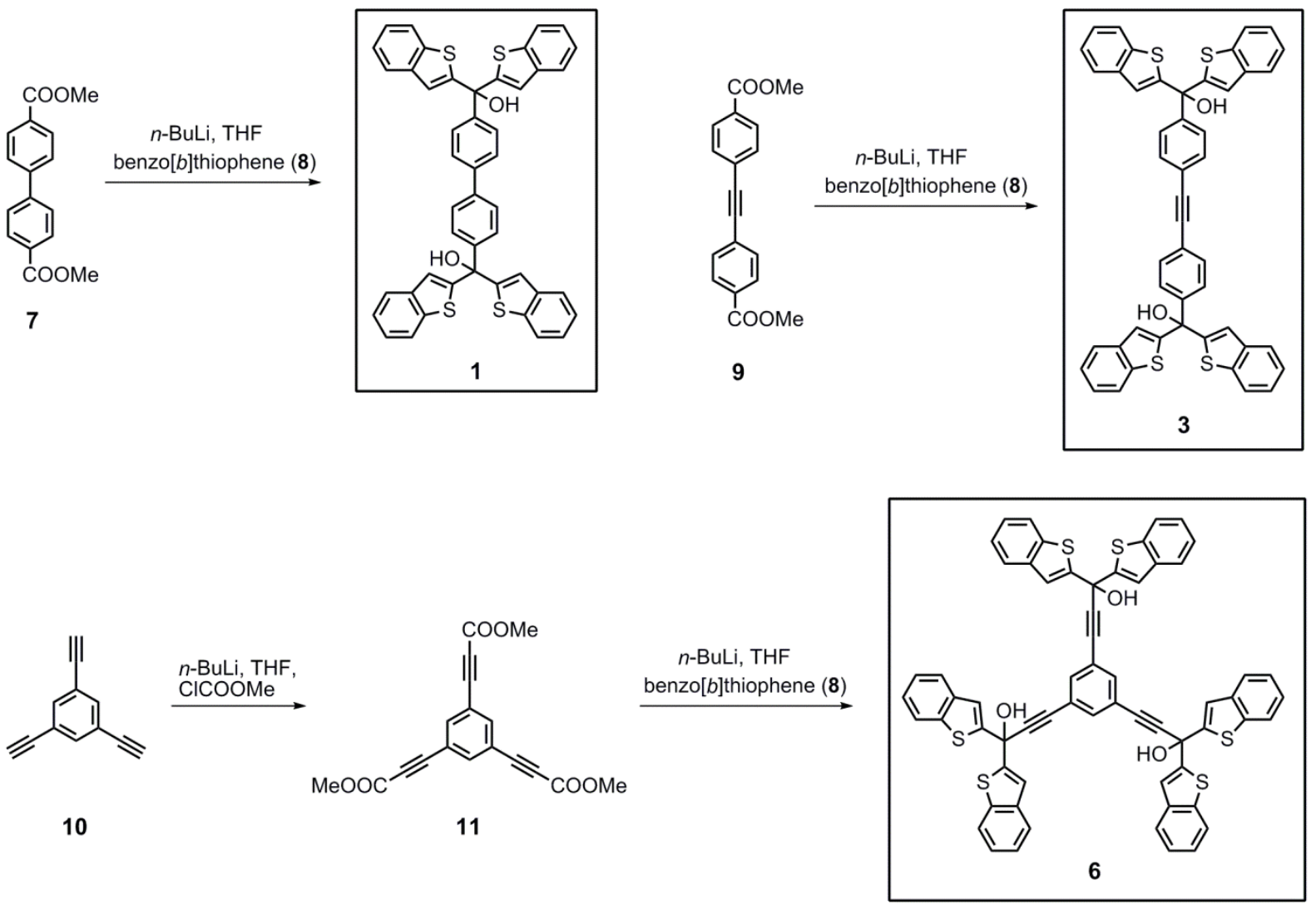

Fig. 2. Synthesis of the host compounds $\mathbf{1}, \mathbf{3}$ and $\mathbf{6}$.

Pd-catalyzed coupling reactions following the Sonogashira-Hagihara protocol [21] were applied to 1,1-di(benzo[b]thien-2-yl)prop-2-yne-1-ol (14) and corresponding diiodides [1,4diiodobenzene, 4,4'-diiodobiphenyl and bis(4-iodophenyl)ethyne] to yield the respective diols 
2, 4 and 5. The basic intermediate 14 was synthesized in three steps starting from benzo $[b]$ thiophene $(\mathbf{8})$ which was reacted with $n$-butyl lithium and $N, N$-dimethylcarbamoyl chloride in dry THF to give di(benzo[b]thien-2-yl)methanone (12). To this latter compound was then added trimethylsilylacetylene (TMSA) in the presence of $n$-butyl lithium leading to the TMS-protected acetylenic alcohol 13 which was deprotected under basic condition $\left(\mathrm{K}_{2} \mathrm{CO}_{3}\right)$ to yield 14.

2

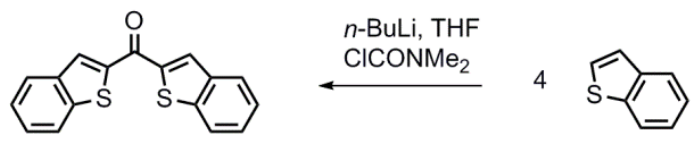

12

8

$\downarrow \begin{gathered}\text { TMSA, } n \text {-BuLi, } \\ \text { THF }\end{gathered}$

2

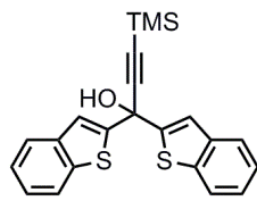

13
$\stackrel{\mathrm{K}_{2} \mathrm{CO}_{3}, \mathrm{MeOH}}{\longrightarrow}$

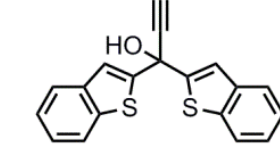

14

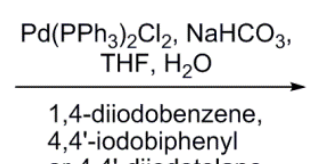

4,4 '-iodobiphenyl
or 4,4 '-diiodotolane

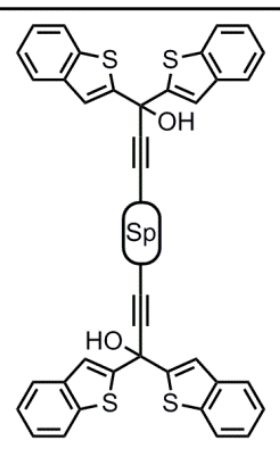

2: $\mathrm{Sp}=$ benzene 4: $\mathrm{Sp}=$ biphenyl 5: $\mathrm{Sp}=$ tolane

Fig. 3. Synthesis of the host compounds $\mathbf{2}, \mathbf{4}$ and $\mathbf{5}$.

Inclusion compounds of 1-6 including the studied solvents were obtained as described in the Experimental.

\section{Capability of inclusion formation}

Previously, we demonstrated that the replacement of thien-2-yl groups of a new prototype host structure [12] by the more bulky benzo[b]thien-2-yl groups giving rise to BTh1 and BTh2 (Fig. 1) leads to a distinct enhancement of the crystalline inclusion formation with organic solvent molecules [13]. Following this line of thought, the question arises whether the intended homologues of BTh1 and BTh2, i.e. 1-6, featuring in their molecular structure an elongated central axis (1-5) or an increased number of bulky lateral groups (6) may cause a further improvement of the inclusion behavior. In order to ensure a sound basis for comparison, a variety of solvents corresponding to those applied to BTh1 and BTh2 were used for the crystallization of 1-6. They range from dipolar protic (alcohols, amines) to largely apolar 
species (chloroform, 1,4-dioxane, toluene) and involve solvents of acyclic and cyclic as well as aliphatic and aromatic or heteroaromatic nature. More detailed specification of the solvents and findings obtained from the crystallization study including the results recently achieved from BTh1 and BTh2 are listed in Table 1.

In general, compound $\mathbf{1}$ is the most efficient one in solvent inclusion (11 hits) and, thus, is comparable with BTh1 (12 hits) and BTh2 (10 hits) by means of the number of inclusions obtained from solvent crystallization. But also hosts 2-4 (9 hits each) are close to the efficacy of the references while 5 (5 hits) and 6 (7 hits) show a decreased inclusion ability. This suggests that increasing the length of the central axis in the molecules (except for $\mathbf{1}$ ) is not always helpful to improve the capacity for solvent inclusion.

Another noticeable point refers to the host:guest stoichiometry of the inclusion compounds. Whereas BTh1 and BTh2 almost universally use 1:2 stoichiometry in the solvent inclusion, the present hosts crystallize with solvents in varying stoichiometries including $3: 1$, $3: 2,1: 1,3: 4,2: 3,1: 2,2: 5,1: 3,1: 4$ and 1:5, i.e. covering a very broad range. For all that, also in this series of compounds the stoichiometric ratio of 1:2 is generally preferred corresponding with the bifunctionality of the host molecules. This is most obviously demonstrated by the inclusion compounds of 5 being only of a low number but having a constant 1:2 stoichiometry. Nevertheless, it is noticed that outstandingly high solvent ratios, up to 1:5, appear rather frequent, and, yet, showing a distinct accumulation for the host molecule $\mathbf{6}$ featuring a trigonal structure.

Regarding the variety of solvents being included it is seen that toluene as a clearly apolar solvent is successfully included from 1, 3, 4 and $\mathbf{6}$ which is in contrast with BTh1 and BTh2 since both do not form respective inclusion compounds. Hence, representatives of the new hosts do not develop such strong limitation to include only solvents of protic and distinctly polar nature as shown for the former hosts. But with reference to the failure of chloroform inclusion they are equivalent. Moreover, all the hosts demonstrate conformity in the inclusion of THF and pyridine followed by acetone which apparently is only unsuccessful with $\mathbf{5}$. The whole of the other dipolar aprotic solvents are rather differently included by the hosts making it difficult to pinpoint a general trend. Remarkably, EtOAc and DMSO are only included by $\mathbf{3}$ and $\mathbf{6}$, respectively, even though the solvent ratio in the case of the DMSO inclusion is markedly high. Distinct differences are also observed in the inclusion formation with protic guests, in particular considering the alcohols showing no correspondence among each other, including BTh1 and BTh2. Virtually, it is obvious from Table 1 that the alcohols show a rather low tendency to be included, resembling in this respect the facts of the former hosts. Hence, in order to provide a 
more profound basis for drawing conclusion extending those from the above findings, a detailed X-ray crystallographic structural study performed of selected inclusion compounds was carried out.

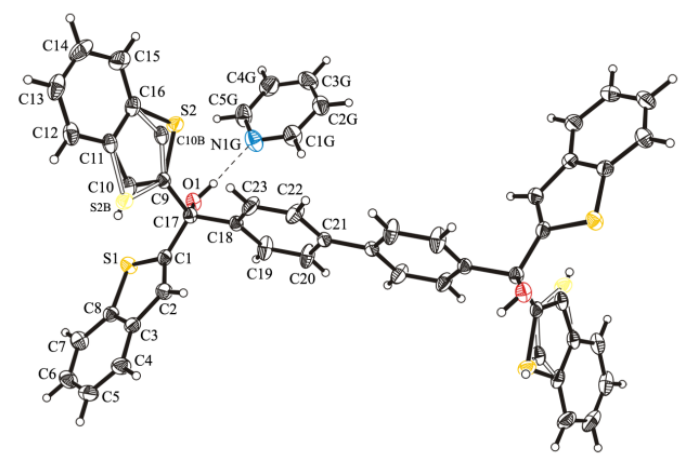

(a)

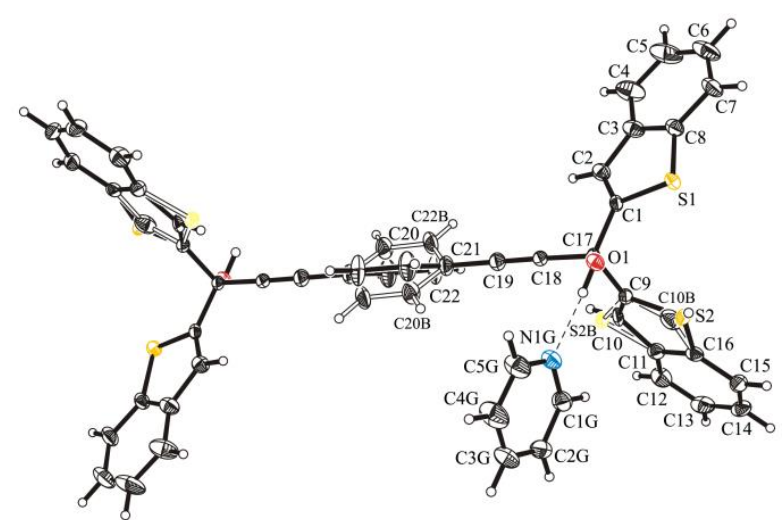

(b)

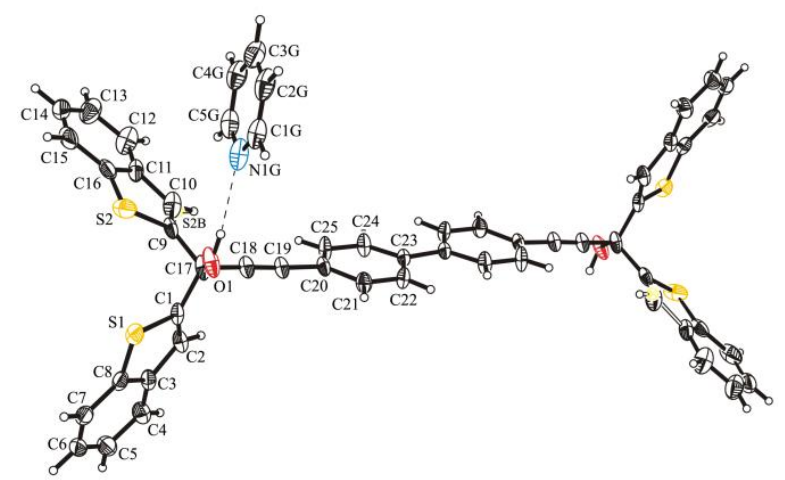

(d)

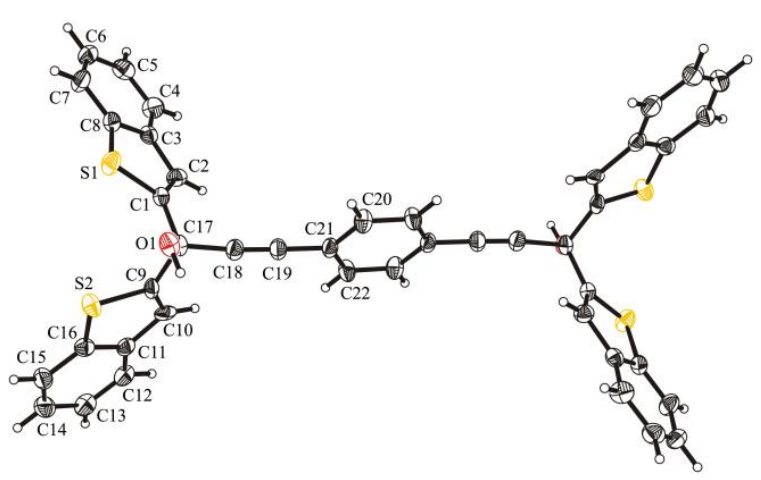

(c)

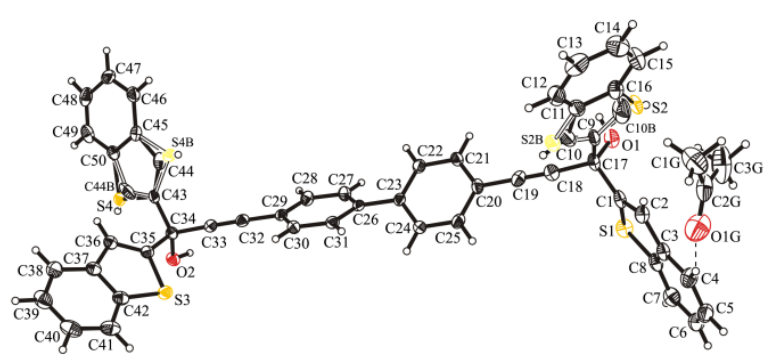

(e) 


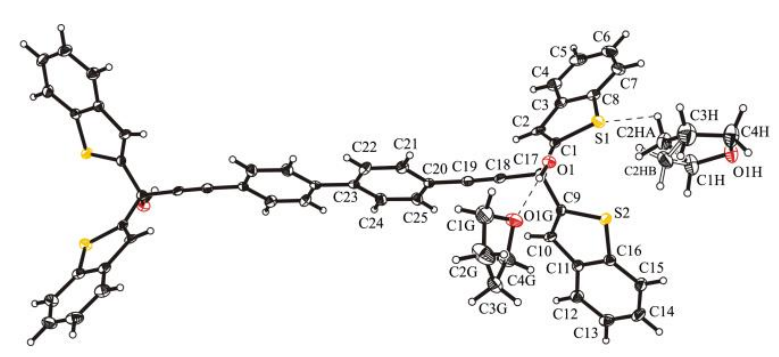

(f)

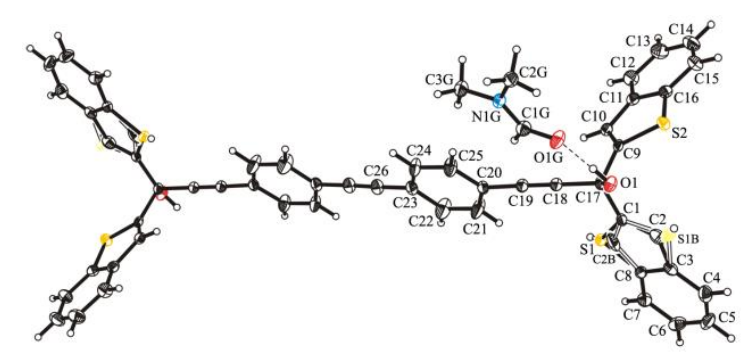

(g)

Fig. 4. Molecular structures of the studied inclusion compounds 1a (a), 2a (b), 2b (c), 4a (d), $\mathbf{4 b}(\mathrm{e}), \mathbf{4 c}(\mathrm{f})$ and $\mathbf{5 a}(\mathrm{g})$ involving atom numbering scheme and specification of disorder sites in 1a, 2a, 4a, 4b, 4c and 5a. (Ellipsoid plots drawn with $50 \%$ probability level.)

Single crystal X-ray structural study

Unfortunately, crystals of inclusion compounds being in a quality for carrying out an Xray structural analysis could only be isolated of the hosts $1,2,4$ and 5, while the hosts 3 and 6 refrained from suitable crystal formation. Nevertheless, a reasonable structural comparison including the prototype hosts BTh1 and BTh2 is possible allowing sufficient insight into the structural circumstances. In detail, the crystalline inclusion compounds which have been studied via X-ray structural analysis involve 1a $(\mathbf{1} \cdot$ pyridine $), \mathbf{2 a}(\mathbf{2} \cdot$ pyridine $), \mathbf{2 b}(\mathbf{2} \cdot n$ $\mathrm{BuOH}), 4 \mathbf{a}(\mathbf{4} \cdot$ pyridine $), \mathbf{4 b}(\mathbf{4} \cdot$ acetone $), \mathbf{4 c}(\mathbf{4} \cdot \mathrm{THF})$ and $5 \mathbf{a}(5 \cdot \mathrm{DMF})$ being itemized in Fig. 1. An especially good opportunity presents itself for structural comparison of the inclusions 1a, 2a and 4a, all containing pyridine, however, showing very different stoichiometric ratios (1a, 1:2; 2a, 1:5; 4a, 1:3). But also the other inclusion compounds (2b, 4b, 4c, 5a) enable an immediate structural comparison based on the same solvent species, even if only included in the crystals of the previous hosts BTh1 and BTh2. Crystal data for the studied compounds are summarized in Table 2. Selected torsion angles of the molecules are listed in Table 3. Packing properties of the studied inclusion compounds are presented in Table 4 and relevant noncovalent interactions found in the crystal structures are given in Table S1 (Supplementary Material). Molecular structures of the inclusion compounds are illustrated in Fig. 4, corresponding packing diagrams and excerpts of packing modes are represented with Figs.511 , respectively.

Irrespective of the particular host molecule, all the inclusion compounds containing pyridine as the guest solvent $(\mathbf{1 a}, \mathbf{2 a}, \mathbf{4 a})$ crystallize in the triclinic space group $P-1$. However, as despite from 1a having half a host molecule and a refined pyridine molecule in the 
asymmetric unit (Fig. 4a), both in 2a (Fig. 4b) and 4a (Fig. 4d) only one of the pyridine molecules could be refined and the residual electron density was removed by the SQUEEZE method of the PLATON program [22]. On the other hand, for the inclusion compounds $\mathbf{2 b}, \mathbf{4} \mathbf{b}$ and $4 \mathbf{c}$, the monoclinic space group $P 2_{1} / c$ (or the alternative setting $P 2_{1} / n$ ) was determined. In 2b (Fig. 4c), the $n$ - $\mathrm{BuOH}$ molecules could not be refined and as before the SQUEEZE method was used to remove the residual electron density, while one of the THF molecules of $\mathbf{4 c}$ (Fig. 4f) shows twofold disorder with a site occupancy factor (sof) of 0.66. As found for 1a, 2a and 4a, the inclusion compound 5a crystallizes in the space group $P-1$ (Fig. 4g). Aside from the specific disorder of solvent molecules, twofold disorder of benzo[b]thiophene units of the host molecules have been observed in 1a (sof=0.90), 2a ( $\operatorname{sof}=0.83), 4 \mathbf{a}$ ( $\operatorname{sof}=0.90), \mathbf{4 b}$ ( $\operatorname{sof}=0.56$, 0.66 ) and $\mathbf{5 a}$ (sof=0.74). Moreover, in the case of $\mathbf{2 a}$, the benzene ring of the spacer element was found to be twofold disordered (sof $=0.69$ ).

\section{Molecular structures}

For the determination of the molecular conformations of the respective hosts, we focused on the one hand on the dihedral angles describing the relative orientations of the two benzo $[b]$ thiophene units and the hydroxyl function. On the other hand, we also incorporated the relative orientations of the phenylene units of the central spacer element to one another and with reference to the orientation of the $\mathrm{OH}$ function. Corresponding torsion angles of the host compound conformations in the crystal structures are summarized in Table 3.

In the structure of 1a (Fig. 4a), the benzene rings of the biphenyl unit are coplanar to each other. The molecular conformation is shown to be stabilized by intramolecular S $\cdots \mathrm{O}$ contacts $[12,23][\mathrm{d}(\mathrm{S} 1 \cdots \mathrm{O} 1)=2.846(1) \AA \mathrm{d}, \mathrm{d}(\mathrm{S} 2 \cdots \mathrm{O} 1)=3.044(1) \AA]$ and can be described by the torsion angles of the heteroaromatic units with reference to the $\mathrm{OH}$ group of $28.3^{\circ}$ (S1-C1C17-O1) and $43.8^{\circ}$ (S2-C9-C17-O1). Regarding the structures of 2a (Fig. 4b) and 2b (Fig. 4c), the alkyne bonds are slightly distorted which is specified by the bond angles of $176.1^{\circ}$ and $177.5^{\circ}$ for $\mathbf{2 a}$ or $175.0^{\circ}$ and $178.4^{\circ}$ for $\mathbf{2 b}$. Just as for $\mathbf{1 a}$, the molecule conformations of the

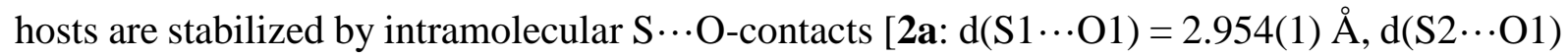
$=2.969(2) \AA ; 2 \mathbf{b}: \mathrm{d}(\mathrm{S} 1 \cdots \mathrm{O} 1)=2.904(3) \AA, \mathrm{d}(\mathrm{S} 2 \cdots \mathrm{O} 1)=2.919(3) \AA]$ giving rise to torsion angles of the heteroaromatic units relative to the $\mathrm{OH}$ groups of $41.0^{\circ} /-35.9^{\circ}$ for $2 \mathbf{a}$ and $26.6^{\circ}$ $33.6^{\circ}$ for $\mathbf{2 b}$ with reference to the atomic sequences S1-C1-C17-O1 and S2-C9-C17-O1, respectively. The host conformations in the structures of $\mathbf{4 a}, \mathbf{4 b}$ and $\mathbf{4 c}$ (Figs. $4 \mathrm{~d}-\mathbf{4 f}$ ) feature 
again stabilization via intramolecular S...O-contacts but involve also intramolecular S $\cdots \mathrm{S}$ contacts [24-26] leading to corresponding torsion angles around the two heteroaromatic and hydroxyl groups as particularized in Table 3. Probably owing to a packing induced distortion of the spacer elements, the alkyne bonds are not linear showing bond angles that range between 176.2 and $179.1^{\circ}$ (with $\mathbf{4 a}$ deviating the most). In contrast to $\mathbf{1 a}$, the biphenyl unit $\mathbf{4 b}$ is not coplanar arranged having an interplanar angle of 38.3.

In the structure of $\mathbf{5 a}$ (Fig. $4 \mathrm{~g}$ ) both the terminal $\left(174.0^{\circ}\right.$ and $\left.176.1^{\circ}\right)$ and the central $\left(178.8^{\circ}\right)$ alkyne bonds are slightly distorted while the benzene rings of the tolane fragment are co-planar. With reference to the conformation including the benzo[b]thiophene units and the $\mathrm{OH}$ group, we notice again the implication of intramolecular $\mathrm{S} \cdots \mathrm{O}$-contacts $[\mathrm{d}(\mathrm{S} 2 \cdots \mathrm{O} 1)=$ $2.966(1) \AA, \mathrm{d}(\mathrm{S} 1 \mathrm{~B} \cdots \mathrm{O} 1)=2.855(5) \AA]$ giving rise to corresponding torsion angles of $-28.6^{\circ}$ (S2-C9-C17-O1) and -151.7 (S1-C1-C17-O1).

\section{Packing structures}

Emphasizing packing density of the different kinds of host-guest complexes (Table 4), particularly noticeable observations are as follows. In case of the inclusion compounds $\mathbf{2 a}$ and $\mathbf{4 c}$ featuring especially high stoichiometric ratios of solvent (5 pyridine and 4 THF molecules per host, respectively), the guest species occupy parts of the unit cells of 48.5 and $37.3 \%$, respectively, which is attended by Kitaigorodskii packing index (KPI) values [27] (without solvent) of 41.2 and $47.7 \%$, respectively. The high framework porosity of $\mathbf{2 a}$ results from channel-like voids in all three crystallographic directions while $\mathbf{4 c}$ imbeds the THF in solvent cages (see below). In comparison, the 1:3 pyridine inclusion 4a contains two different solvent channels $(A$ and $B)$ along the $a$-axis and possess a KPI value (without solvent) of $51.8 \%$ offering $31.8 \%$ solvent accessible void (SAV) in the unit cell. The 1:2 inclusion compounds $\mathbf{1 a}$ (pyridine), $\mathbf{2 b}(n-\mathrm{BuOH})$ and $\mathbf{5 a}(\mathrm{DMF})$ form frameworks which show KPI values (without solvent) of 54.5, 56.9 and $58.4 \%$ and SAVs of 26.9, 22.0 and $17.2 \%$, respectively, depending both on the guest volume and property which influence the packing of the host molecules. The closest packing of the investigated structures is formed of the 1:2 DMF inclusion compound 5a with a KPI value (with solvent) of $70.6 \%$ followed by the $1: 1$ acetone host-guest compound $\mathbf{4 b}$ having a KPI value (with solvent) of $70.5 \%$.

Regarding a more detailed discussion on the molecular arrangement including a description of intermolecular interactions modes, the structures can be described as follows. In 
the structure of the inclusion compound 1a, the host molecules are lined up in strands along the crystallographic $b$-axis connected by weak $\mathrm{C}-\mathrm{H} \cdots \mathrm{O}$-hydrogen bonding $[28][\mathrm{d}(\mathrm{C} 19 \cdots \mathrm{O} 1)=$ 3.339(2) $\AA$ ] with the graph set $\mathrm{R}_{2}^{2}(10)$ [29] (Fig. 5a). The strands are linked in the $a$-direction via $\mathrm{C}-\mathrm{H} \cdots \pi$-interactions $[30,31][\mathrm{d}(\mathrm{C} 2 \cdots \mathrm{Cg} 9)=3.564(2) \AA, \mathrm{d}(\mathrm{C} 7 \cdots \mathrm{Cg} 8)=3.475(2) \AA$, $\mathrm{d}(\mathrm{C} 15 \cdots \mathrm{Cg} 5)=3.630(2) \AA]$ while in $c$-direction $\mathrm{C}-\mathrm{H} \cdots \pi-[\mathrm{d}(\mathrm{C} 13 \cdots \mathrm{Cg} 7)=3.770(2) \AA]$ and $\mathrm{C}-\mathrm{H} \cdots \mathrm{S}$-contacts $[32][\mathrm{d}(\mathrm{C} 4 \cdots \mathrm{S} 2 \mathrm{~B})=3.485(4) \AA(10 \%), \mathrm{d}(\mathrm{C} 5 \cdots \mathrm{S} 2 \mathrm{~B})=3.459(6) \AA(10 \%)]$ participate in the stabilization of the crystal. The pyridine guest molecules are included cagelike in the packing structure (Fig. 5b) and are fixed to the host hydroxyls by strong $\mathrm{O}-\mathrm{H} \cdots \mathrm{N}-$ hydrogen bonds $[\mathrm{d}(\mathrm{O} 1 \cdots \mathrm{N} 1 \mathrm{G})=3.339(2) \AA]($ Fig. 5a), C-H $\cdots \pi-[\mathrm{d}(\mathrm{C} 23 \cdots \mathrm{Cg} 10)=3.650(2)$ $\AA, d(C 1 G \cdots C g 5)=3.685(2) \AA]$ and $\pi \cdots \pi$-interactions $[33,34](d=3.944 \AA)$ among each other.

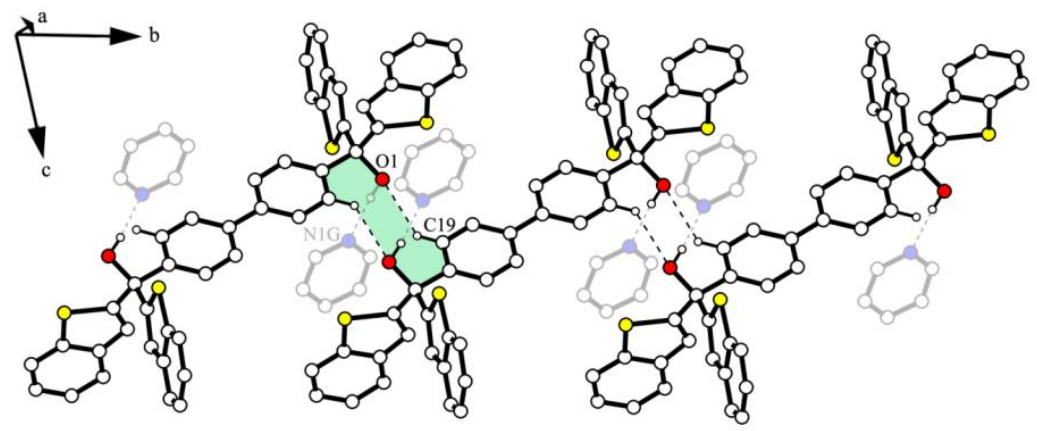

(a)

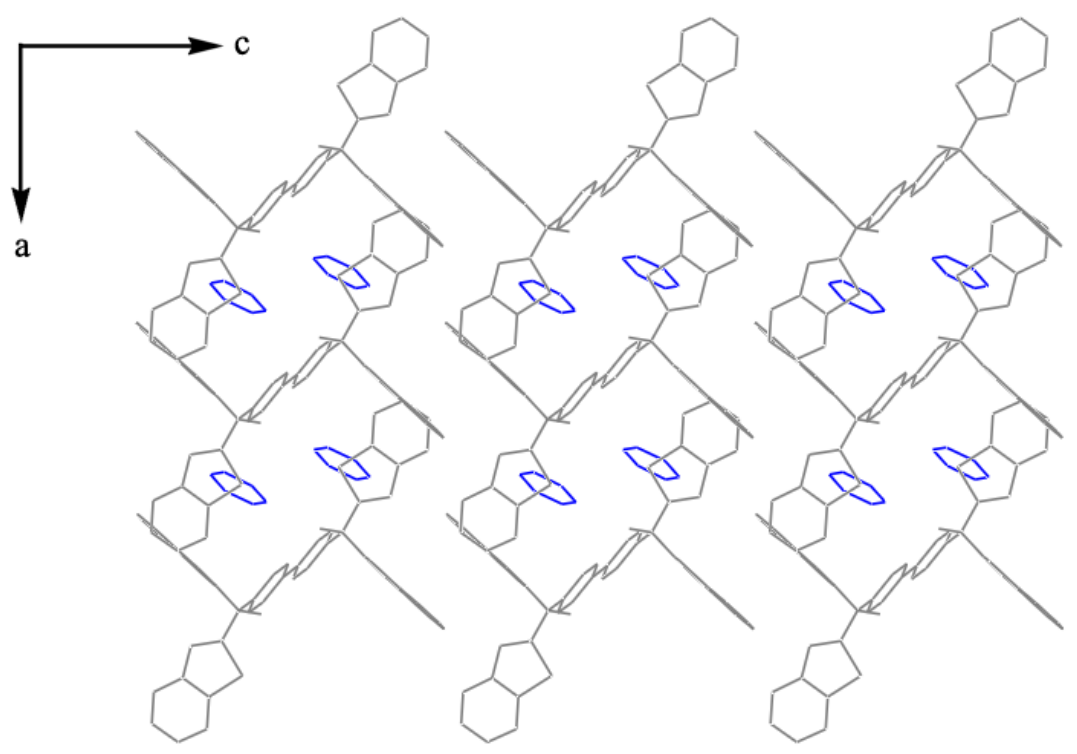

(b)

Fig. 5. Illustration of the structure 1a: (a) Host molecule strand showing hydrogen bond ring motif $\mathrm{R}_{2}^{2}(10)$ and linkage of pyridine. (b) Cage-like packing structure. Non-relevant $\mathrm{H}$-atoms are omitted for clarity. 
Strand formation of host molecules is also observed in the structure of $\mathbf{2 a}$ with hosts being connected along the [110]- as well as in $b$-direction by $\mathrm{C}-\mathrm{H} \cdots \pi$-interactions $[\mathrm{d}(\mathrm{C} 6 \cdots \mathrm{Cg} 5)$

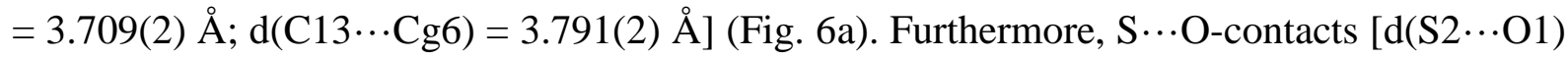
= 3.150(2) $\AA$ ] give rise to the stabilization of the packing in the [011]-direction thus featuring a highly porous network structure exhibiting solvent channels in all three crystallographic directions (Fig. 6b). The refined pyridine guest molecule is included in the channel along the $c$ axis being attached to host molecules by $\mathrm{O}-\mathrm{H} \cdots \mathrm{N}$-hydrogen bonding $[\mathrm{d}(\mathrm{O} 1 \cdots \mathrm{N} 1 \mathrm{G})=2.748(2)$ $\AA$ ] and $\mathrm{C}-\mathrm{H} \cdots \pi$-interactions $[\mathrm{d}(\mathrm{C} 1 \mathrm{G} \cdots \mathrm{Cg} 4)=3.778(2) \AA, \mathrm{d}(\mathrm{C} 2 \mathrm{G} \cdots \mathrm{Cg} 1)=3.675(2) \AA$, $\mathrm{d}(\mathrm{C} 3 \mathrm{G} \cdots \mathrm{Cg} 2)=3.516(2) \AA]$.



(a)
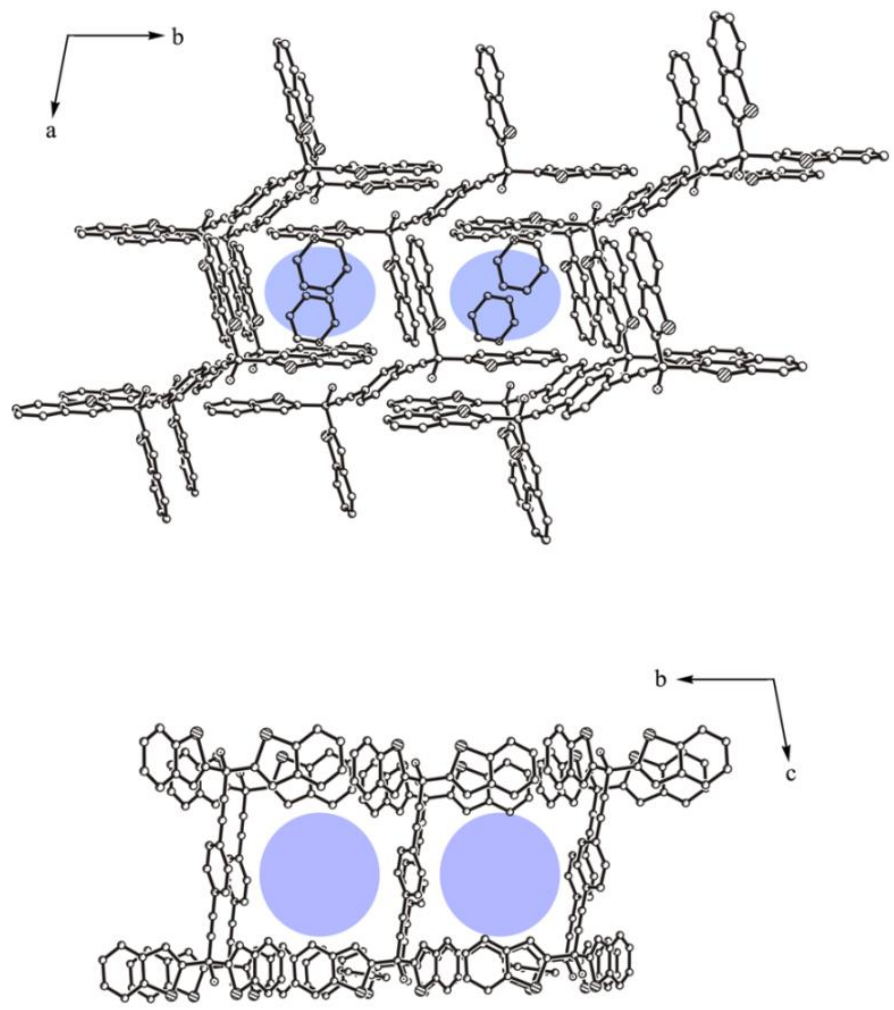

(b) 
Fig. 6. Illustration of the structure 2a: (a) Host molecule strand involving linkage of pyridine. (b) Channel-like packing structure viewed in two different directions. Non-relevant H-atoms are omitted for clarity.

Similar to before, host molecules in the structure of $\mathbf{2 b}$ form chains (here along the $b$ axis) but now being stabilized by strong $\mathrm{O}-\mathrm{H} \cdots \mathrm{O}$-hydrogen bonds $[\mathrm{d}(\mathrm{O} 1 \cdots \mathrm{O} 1)=2.773(5) \AA]$ between the host $\mathrm{OH}$ groups (Fig. 7a). In addition, the host chains are stabilized in $a$-direction via $\mathrm{C}-\mathrm{H} \cdots \mathrm{S}-[\mathrm{d}(\mathrm{C} 7 \cdots \mathrm{S} 2)=3.658(4) \AA]$ and $\mathrm{C}-\mathrm{H} \cdots \pi$-interactions $[\mathrm{d}(\mathrm{C} 5 \cdots \mathrm{Cg} 4)=3.631(4) \AA]$ while in $c$-direction only $\mathrm{C}-\mathrm{H} \cdots \mathrm{S}$-contacts $[\mathrm{d}(\mathrm{C} 12 \cdots \mathrm{S} 1)=3.657(4) \AA$ ] $]$ occur. The hydrogen atoms of the host hydroxyls show twofold disorder (sof =0.57) and are thus labeled in Fig. 7a as $\mathrm{H} 1 \mathrm{~B}$ linking the host molecules and H1A probably connecting the included $n$ - $\mathrm{BuOH}$ guest. It follows from this that the guest molecules are accommodated in host channels extending along the crystallographic $b$-axis (Fig. 7b).

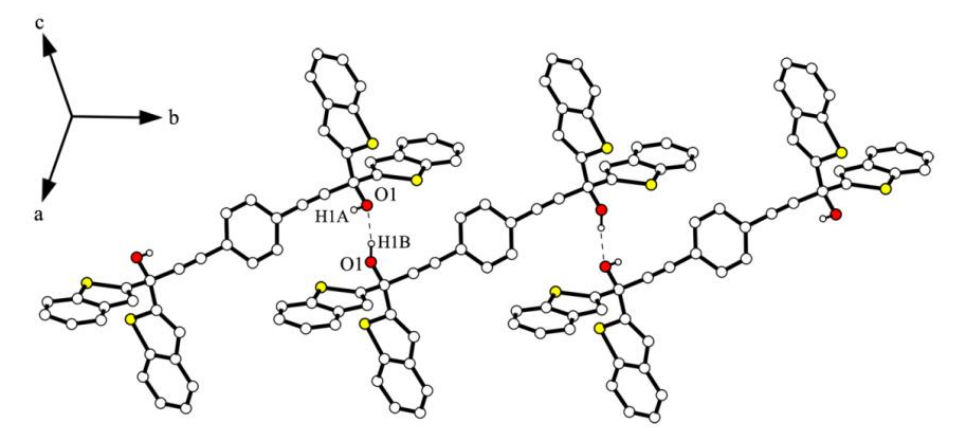

(a)
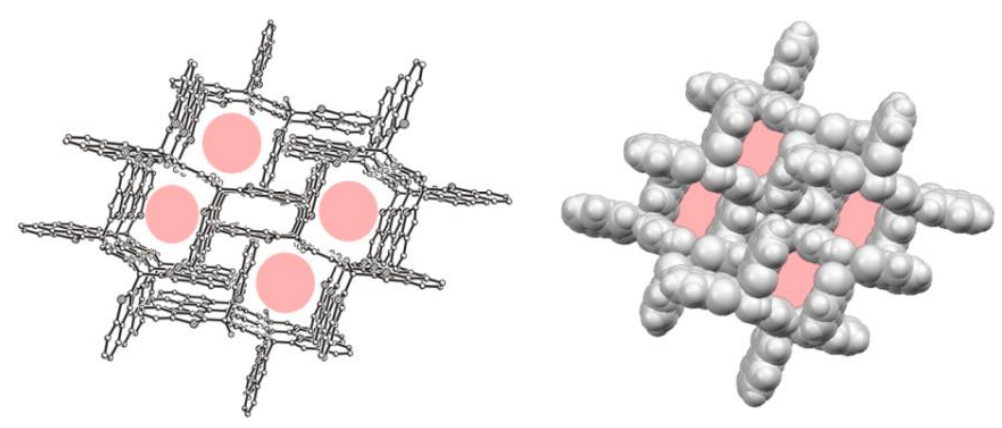

(b)

Fig. 7. Illustration of the structure 2b: (a) Host molecule chain showing twofold disorder of the hydroxyl group. (b) Channel-like packing structure in the crystallographic $b$-direction and respective Van-der-Waals model. Non-relevant H-atoms were omitted for clarity. 
Again, the packing structure of $\mathbf{4 a}$ is composed of strand-like connected host molecules. The strands developed in this way run along the crystallographic $a$-axis and are stabilized both by weak $\mathrm{C}-\mathrm{H} \cdots \mathrm{O}-$ hydrogen bonding $[\mathrm{d}(\mathrm{C} 25 \cdots \mathrm{O} 1)=3.424(3) \AA]$ and $\mathrm{C}-\mathrm{H} \cdots \mathrm{S}$-contacts $[\mathrm{d}(\mathrm{C} 12 \cdots \mathrm{S} 2)=3.511(3) \AA]$ (Fig. 8a). In the $b$-direction, the strands interact via $\mathrm{C}-\mathrm{H} \cdots \pi-$ contacts $[\mathrm{d}(\mathrm{C} 5 \cdots \mathrm{Cg} 5)=3.494(3) \AA]$; in $c$-direction via $\mathrm{C}-\mathrm{H} \cdots \pi-[\mathrm{d}(\mathrm{C} 14 \cdots \mathrm{Cg} 3)=3.712(3) \AA]$ and additional $\mathrm{C}-\mathrm{H} \cdots \mathrm{S}-$ contacts $[\mathrm{d}(\mathrm{C} 15 \cdots \mathrm{S} 2)=3.705(3) \AA]$. Based on this arrangement, two different solvent channels (A and B) are formed along the crystallographic $a$-axis (Fig. 8b). The refined pyridine molecules are accommodated within the channels of type A fixed by $\mathrm{O}-\mathrm{H} \cdots \mathrm{N}-$ host-guest hydrogen bonding $[\mathrm{d}(\mathrm{O} 1 \cdots \mathrm{N} 1 \mathrm{G})=3.110(3) \AA]$ which according to the bond length should only be rated of moderate strength. Nevertheless, additional $\mathrm{C}-\mathrm{H} \cdots \pi$-interactions $[\mathrm{d}(\mathrm{C} 7 \cdots \mathrm{Cg} 6)=3.581(2) \AA, \mathrm{d}(\mathrm{C} 5 \mathrm{G} \cdots \mathrm{Cg} 4)=3.562(3) \AA]$ take part in guest fixation. The second guest channel (B) contains the pyridine molecules which could not be refined.

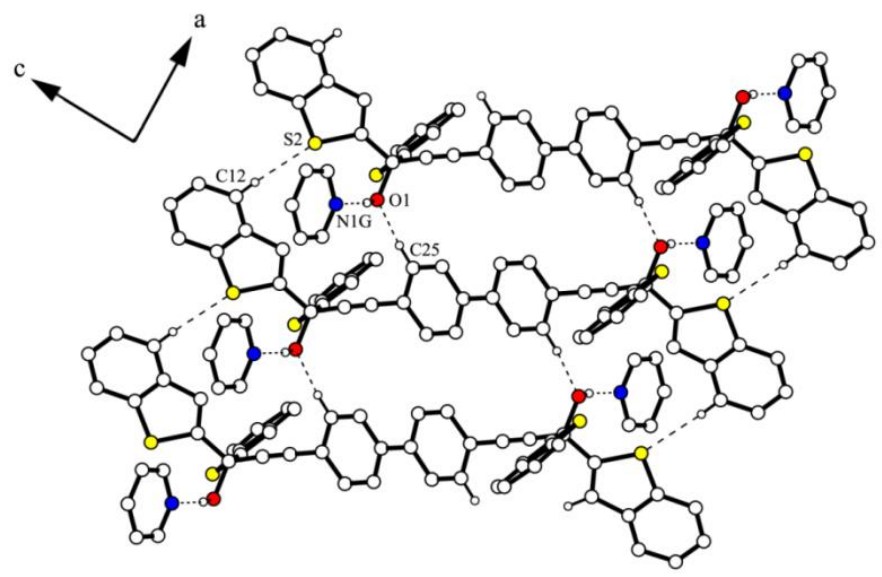

(a)

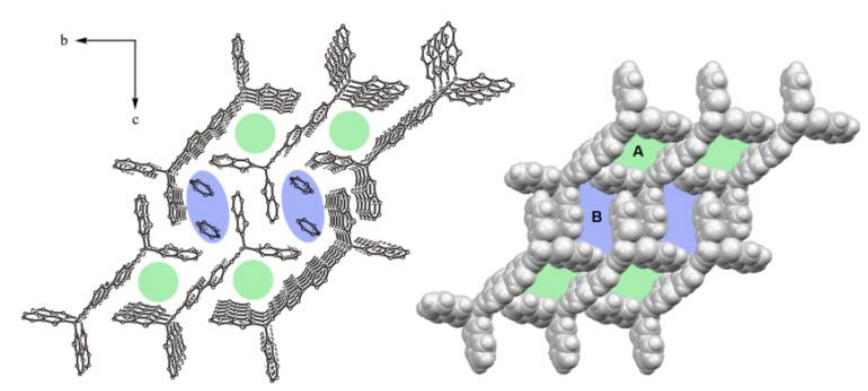

(b)

Fig. 8. Illustration of the structure 4a: (a) Host molecule strand involving linkage of pyridine. (b) Channel-like packing structure and Van-der-Waals model (channel $\mathrm{A}=$ unrefined pyridine, channel $\mathrm{B}=$ refined pyridine). Non-relevant $\mathrm{H}$-atoms are omitted for clarity. 
In the crystals of $\mathbf{4 b}$, the host molecules occur as dimers connected by strong $\mathrm{O}-\mathrm{H} \cdots \mathrm{O}-$ hydrogen bonds $[\mathrm{d}(\mathrm{O} 2 \cdots \mathrm{O} 1)=3.168(2) \AA]$ and $\mathrm{C}-\mathrm{H} \cdots \mathrm{S}$-contacts $[\mathrm{d}(\mathrm{O} 2 \cdots \mathrm{S} 1)=3.550(1) \AA]$ forming a hydrogen bond ring motif with the graph set $\mathrm{R}_{1}^{2}(5)$ with the hydroxyl group $\mathrm{O} 2-\mathrm{H} 2 \mathrm{~A}$ being in an inverse bifurcated situation (Fig. 9a). Furthermore, C-H $\cdots \pi$-interactions $[\mathrm{d}(\mathrm{C} 27 \cdots \mathrm{Cg} 9)=3.484(2) \AA, \mathrm{d}(\mathrm{C} 7 \cdots \mathrm{Cg} 16)=3.517(2) \AA]$ between the biphenyl as well as between the benzo[b]thiophene units support the dimer stabilization. The host dimers are linked in the [101]- and [301]-directions, and also along the $b$-axis via $\mathrm{C}-\mathrm{H} \cdots \pi$-interactions $[\mathrm{d}(\mathrm{C} 46 \cdots \mathrm{Cg} 12)=3.509(2) \AA ; \mathrm{d}(\mathrm{C} 14 \cdots \mathrm{Cg} 11)=3.706(2) \AA ; \mathrm{d}(\mathrm{C} 5 \cdots \mathrm{Cg} 4)=3.495(2) \AA$, $\mathrm{d}(\mathrm{C} 24 \cdots \mathrm{Cg} 7)=3.673(2) \AA, \mathrm{d}(\mathrm{C} 31 \cdots \mathrm{Cg} 14)=3.538(2) \AA]$ while additional $\mathrm{C}-\mathrm{H} \cdots$ S-contacts $[\mathrm{d}(\mathrm{C} 21 \cdots \mathrm{S} 4)=3.642(2) \AA]$ occur in the $b$-direction. Against expectation, but obviously caused by the packing arrangement, the hydroxyl group $\mathrm{O} 1-\mathrm{H} 1$ of the host is unable to act as a donor of a conventional hydrogen bond and is pointing towards an aromatic unit of an adjacent dimer. As a result of this, the acetone guest molecules are included cage-like (Fig. 9b) and fixed only by weak $\mathrm{C}-\mathrm{H} \cdots \mathrm{O}$-hydrogen bonding $[\mathrm{d}(\mathrm{C} 38 \cdots \mathrm{O} 1 \mathrm{G})=3.463(3) \AA]$ and $\mathrm{C}-\mathrm{H} \cdots \mathrm{S}$-contacts $[\mathrm{d}(\mathrm{C} 3 \mathrm{G} \cdots \mathrm{S} 2)=3.855(3) \AA]$ involving the benzo[b]thiophene unit (Fig. 9a).

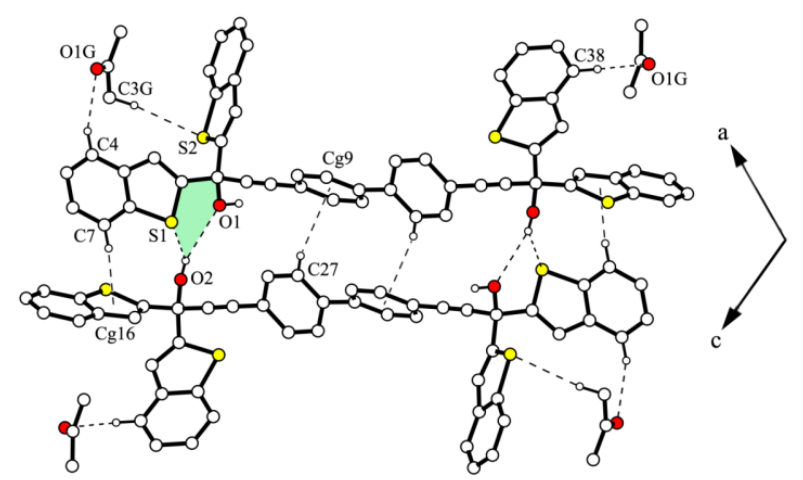

(a)

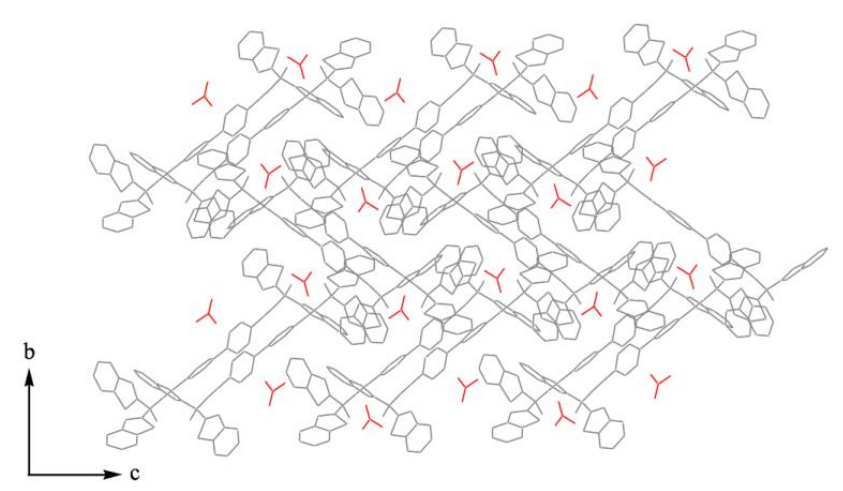

(b) 
Fig. 9. Illustration of the structure 4b: (a) Host molecule dimer showing hydrogen bond ring motif $\mathrm{R}_{1}^{2}(5)$ and linkage of acetone. (b) Cage-like packing structure. Non-relevant $\mathrm{H}$-atoms are omitted for clarity.

The crystal of $\mathbf{4 c}$ is composed of layers of host molecules running parallel to the [-102]plane with hosts being stabilized strand-like along the crystallographic $b$-axis using $\mathrm{C}-\mathrm{H} \cdots \pi$ interaction $[\mathrm{d}(\mathrm{C} 5 \cdots \mathrm{Cg} 6)=3.509(2) \AA]$ (Fig. 10a). Adjacent strands within a layer are oriented in opposite directions and connected among each other again by means of $\mathrm{C}-\mathrm{H} \cdots \pi$-interaction $[\mathrm{d}(\mathrm{C} 7 \cdots \mathrm{Cg} 2)=3.509(2) \AA, \mathrm{d}(\mathrm{C} 15 \cdots \mathrm{Cg} 7)=3.509(2) \AA]$. The THF guest molecules are intercalated between the host layers (Fig. 10b). One of the solvent molecules (THF1) is connected via a strong $\mathrm{O}-\mathrm{H} \cdots \mathrm{O}$-hydrogen bond $[\mathrm{d}(\mathrm{O} 1 \cdots \mathrm{O} 1 \mathrm{G})=3.463(3) \AA]$ (Fig. 10a) and a $\mathrm{C}-\mathrm{H} \cdots \pi$-interaction $[\mathrm{d}(\mathrm{C} 3 \mathrm{G} \cdots \mathrm{Cg} 4)=3.509(2) \AA]$ to a corresponding layer while connection to the adjacent host layer is enabled also using $\mathrm{C}-\mathrm{H} \cdots \pi$-interaction $[\mathrm{d}(\mathrm{C} 1 \mathrm{G} \cdots \mathrm{Cg} 6)=3.509(2)$ $\AA$ ]. In contrast, the THF molecule 2 is linked to one layer by weak $\mathrm{C}-\mathrm{H} \cdots \mathrm{O}$-hydrogen bonds $[\mathrm{d}(\mathrm{C} 10 \cdots \mathrm{O} 1 \mathrm{H})=3.463(3) \AA, \mathrm{d}(\mathrm{C} 25 \cdots \mathrm{O} 1 \mathrm{H})=3.463(3) \AA]$ (Fig. 10a) with the THF oxygen $\mathrm{O} 1 \mathrm{H}$ being in a bifurcated situation, thus in a position to connect the adjacent host layer via $\mathrm{C}-$ $\mathrm{H} \cdots \pi$-interactions $[\mathrm{d}(\mathrm{C} 3 \mathrm{HB} \cdots \mathrm{Cg} 6)=3.497(1) \AA ̊ . \mathrm{d}(\mathrm{C} 4 \mathrm{HA} \cdots \mathrm{Cg} 6)=3.654(8) \AA]$.

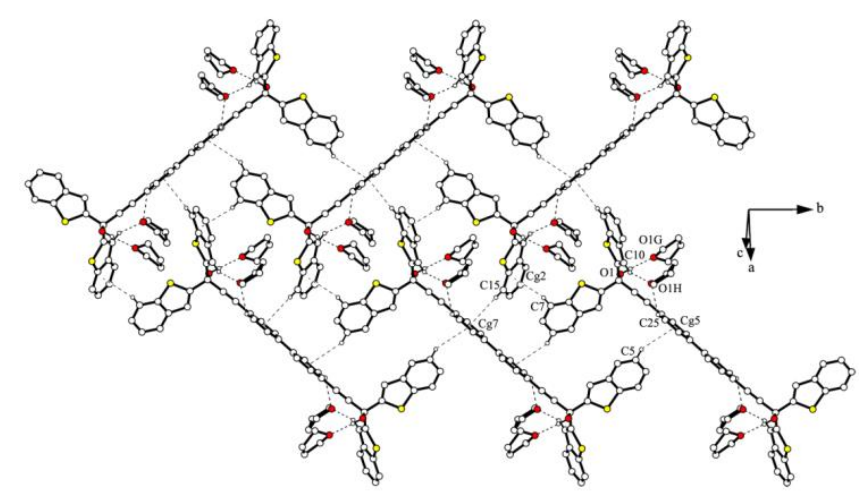

(a)

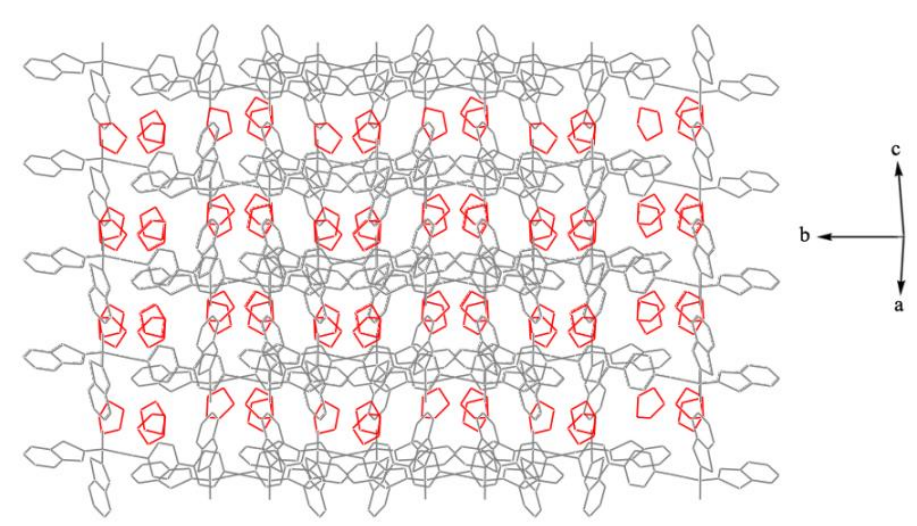

(b) 
Fig. 10. Illustration of the structure 4c: (a) Host layer showing linkage of THF. (b) Layer-like packing structure. Non-relevant $\mathrm{H}$-atoms are omitted for clarity.

Layers of host molecules are also a main building principle of the crystal formed of $\mathbf{5 a}$. They run parallel to the [001]-plane and, as before, consist of strands of host molecules (Fig. 11). Along the crystallographic $a$-axis, the strands are connected by $\mathrm{C}-\mathrm{H} \cdots \pi-[\mathrm{d}(\mathrm{C} 24 \cdots \mathrm{Cg} 4)=$ $3.497(1) \AA]$ as well as $\pi \cdots \pi$-interaction $[\mathrm{d}(\mathrm{Cg} 1 \cdots \mathrm{Cg} 5)=3.984(1) \AA]$ and in the $b$-direction via $\mathrm{C}-\mathrm{H} \cdots \mathrm{S}-$ contact $[\mathrm{d}(\mathrm{C} 15 \cdots \mathrm{S} 1)=3.642(2) \AA]$. The intercalated DMF guests link the host layers (Fig. 11a) resulting in a hydrogen bond ring motif with the graph set $\mathrm{R}_{4}^{2}(18)$, which has not been reported before in the literature. Thereby, strong $\mathrm{O}-\mathrm{H} \cdots \mathrm{O}-[\mathrm{d}(\mathrm{O} 1 \cdots \mathrm{O} 1 \mathrm{G})=3.463(3) \AA]$ and weak $\mathrm{C}-\mathrm{H} \cdots \mathrm{O}$-hydrogen bonds $[\mathrm{d}(\mathrm{C} 4 \cdots \mathrm{O} 1 \mathrm{G})=3.463(3) \AA]$ are involved with the DMF oxygen $\mathrm{O} 1 \mathrm{G}$ showing inverse bifurcation. In addition, $\mathrm{C}-\mathrm{H} \cdots \pi$-interactions $[\mathrm{d}(\mathrm{C} 2 \mathrm{G} \cdots \mathrm{Cg} 7)=$ $\left.3.497(1) \AA, \mathrm{d}\left(\mathrm{C} 3 \mathrm{G} \cdots \mathrm{C} 88_{\mathrm{Ar}}\right)=3.497(1) \AA, \mathrm{d}(\mathrm{C} 3 \mathrm{G} \cdots \mathrm{Cg} 6)=3.497(1) \AA\right]$ between the DMF methyl groups and aromatic units of the hosts as well as a $\mathrm{C}-\mathrm{H} \cdots \pi$-interaction $[\mathrm{d}(\mathrm{C} 1 \mathrm{G} \cdots \mathrm{Cg} 9)$ = 3.497(1) $\AA$ ] including the DMF formyl hydrogen and a terminal alkyne unit of the host give rise to the stabilization of the packing.

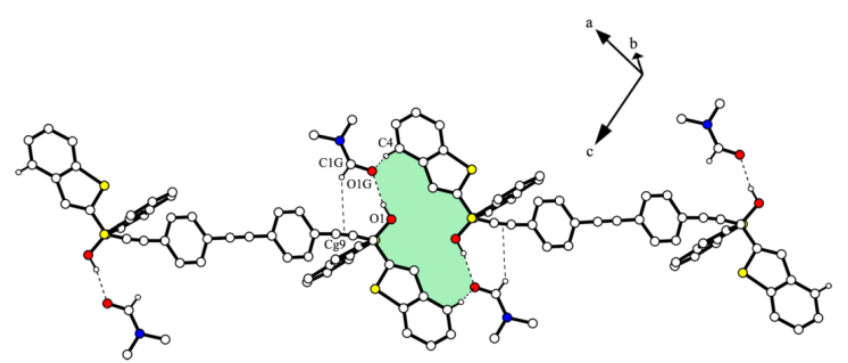

(a)

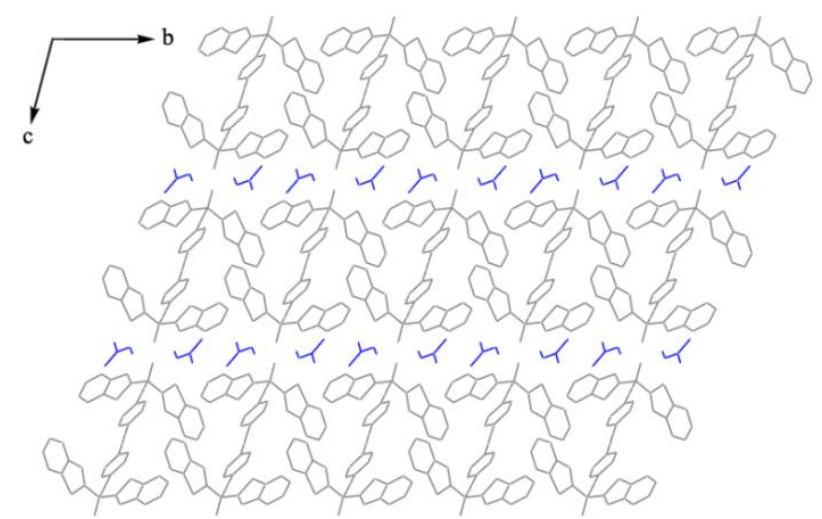

(b) 
Fig. 11. Illustration of the structure 5a: (a) Linkage of the host molecules of adjacent layers by DMF mediated connection. (b) Layer-like packing structure. Non-relevant $\mathrm{H}$-atoms are omitted for clarity.

\section{Solvent vapor absorption behavior}

The diol host compounds $\mathbf{1}$ - $\mathbf{6}$ were deposited as solvent-free thin films from $\mathrm{CHCl}_{3}$ solution on a quartz crystal microbalance [14] and investigated in view of their vapor absorption. Hereby, the corresponding gas-sensing process, i.e. the solvent vapor sorption, is represented by the incorporation of the analyte into the chemical layer deposited on the quartz crystal, leading to a mass increase. As a result, the resonance frequency of the quartz crystal is shifted delivering information on the amount of the incorporated solvent [35]. To enable a sound comparison with previous data obtained from BTh1 and BTh2 [13], a series of different solvent vapors being in correspondence with a former selection of vapors $[12,13]$ was used. They involve vapors of $n$-hexane, $\mathrm{CHCl}_{3}$, THF, acetone, EtOH and $\mathrm{Et}_{2} \mathrm{NH}$. The vapor absorption ratios of 1-6 including those of BTh1 and BTh2 for comparative purpose are listed in Table 5 and corresponding bar graphs are shown in Fig. 12.

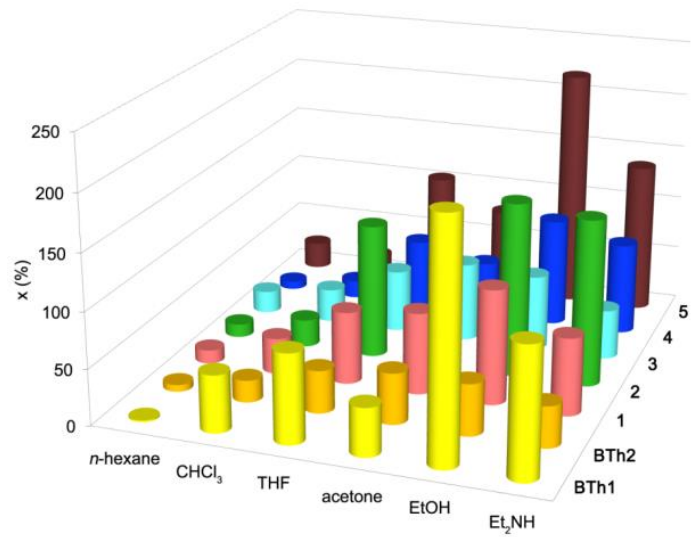

(a) 


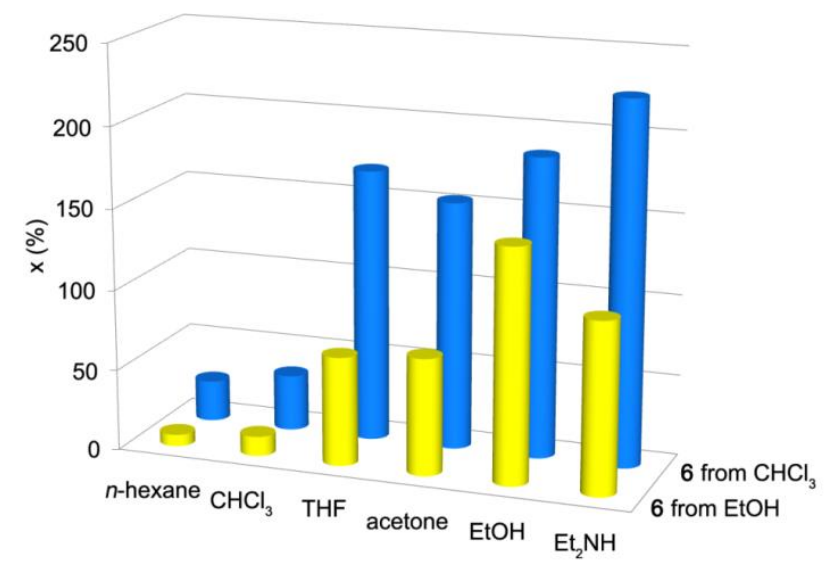

(b)

Fig. 12. Vapor absorption diagrams of the hosts $\mathbf{1}$ - $\mathbf{5}$ in comparison with BTh1 and BTh2 (a) as well as of the host $\mathbf{6}$ coated from different solvents (b).

As expected, the vapor of the least polar solvents, i.e. $n$-hexane and $\mathrm{CHCl}_{3}$ show the lowest absorption ratio, no matter which host compound is used for coating. In reversal conclusion, vapors of the more polar and protic solvents feature a much higher absorption being expressed by increased absorption ratios (100\% equals an inclusion stoichiometry of 1:1, 200 $\%$ of $1: 2$ etc. [36]); this is particularly true for the vapors of $\mathrm{EtOH}$ and $\mathrm{Et}_{2} \mathrm{NH}$. Nevertheless, for each coating sorption ratios depend on host structure and its packing in the solid state. However, since the structures of solvent-free crystals of 1-6 are not known, it is difficult to deliver a sound reasoning based on an appropriate approach. To specify a few facts of noteworthy behavior: BTh1 and compound $\mathbf{5}$ demonstrate particular high activity of sorption for $\mathrm{EtOH}$ (212\% and $218 \%$ ratios, respectively, equating to approximate 1:2 host-guest stoichiometries), though both compounds feature very different lengths of the central molecular axes and appear as rather inefficient referring to their inclusion from solvent crystallization. The same we found for the sorption of $\mathrm{Et}_{2} \mathrm{NH}$ by 6 (coated from $\mathrm{CHCl}_{3}$ ) showing the highest ratio of vapor uptake on the whole ( $224 \%$ ); though 6 failed to make accessible a corresponding inclusion complex on solvent crystallization. From another approach of reasoning one may think that the spatial condition near the binding active hydroxyl group of the host exercises a controlling influence on the vapor sorption. This would mean that the hosts featuring an ethynylene unit attached to the hydroxyl substituted carbon atom (BTh1, 2, 4-6) are favored over hosts having an attached phenylene unit $(\mathbf{B T h 2}, \mathbf{1}, \mathbf{3})$; but also in this respect there is no corresponding trend justified by the data. Hence, the results once more $[12,13,36]$ make us aware that the vapor sorption behavior and solvent co-crystallization properties of the present hosts are only limited, if at all, transferable. 
In further studies, we observed a preconditioning effect of the sorptive coating. This has been found working with host compound $\mathbf{6}$ showing high ratios of included EtOH both on solvent crystallization (1:4 stoichiometry) and vapor sorption (185\%) when 6 having been deposited from $\mathrm{CHCl}_{3}$ solution. However, when the quartz crystal was dipped in a $0.01 \mathrm{M}$ solution of $\mathbf{6}$ in EtOH and the solvent was evaporated aiming for a solvent-free and loosely packed coating, sorption measurements with the guest vapors applied before, revealed a different outcome of the experiment instead. The uptake of all guest vapors is decreased now in comparison to the coating of 6 from chloroform ranging from $-22 \%$ for $\mathrm{EtOH}$ and $-72 \%$ for $n$-hexane. Moreover, the sequence of the different solvents has changed. $\mathrm{Et}_{2} \mathrm{NH}$ which was taken up in the highest ratio before, is now absorbed only moderately. The smallest change has been observed for EtOH as a guest vapor (Table 5, Fig. 12b). This remarkable finding might be explained by a kind of 'structure memory effect' [37,38] of the voids remained after solvent desorption of the initial host-guest coating.

\section{Conclusion}

Carbonyl addition reactions of benzo[b]thien-2-yl-lithium to corresponding di- or triesters in the cases of $\mathbf{1 ,} 3$ and $\mathbf{6}$, respectively, and Sonogashira-Hagihara cross-coupling reactions between a particular benzo[b]thien-2-yl substituted propynol (14) and corresponding spacer moieties in the cases of $\mathbf{2 , 4}$ and $\mathbf{5}$ gave the new diol compounds in respective to high yields (54-96\%). An intensive study of the inclusion property in solid state by crystallization from a variety of solvents proved their versatile host behavior and inclusion activity. Other than we expected, elongation of the central spacer unit does not improve the inclusion behavior in general. This is in line with findings for gradually elongated porphyrin systems [8,9]. The most efficient solvent inclusion has been found for a biphenyl spacer showing an inclusion ratio comparable to previously discussed molecules having phenyl or an ethynlene spacer. By way of interest, for the new compounds, high ratio of included solvent is rather common, which is especially true for the trigonal host $\mathbf{6}$.

From seven inclusion compounds X-ray structures could be solved. The structural investigation revealed the dominance of layers, cages and channels, with the guests being accommodated in the respective voids. A particular high framework porosity is observed for the 1:5 pyridine inclusion 2a indicating ideal spacer length for optimal bulkiness of the host; for this example a KPI of only $41.2 \%$ has been found. As before for the tendency to form 
crystalline inclusion compounds, the ability for QCM vapor absorption is rarely depending on the spacer length, though much more on the spacer components. The ratio of vapor absorption is notably high for the $\mathrm{C} \equiv \mathrm{C}-\mathrm{Ph}-\mathrm{C} \equiv \mathrm{C}$ spacer occurring either two (2) or three (6) times in the respective host. For $\mathbf{6}$ as the most active of the hosts studied here, the use of different solvents on the quality of the coating has been investigated. Thereby, a 'structure memory effect' shown for the inclusion of EtOH instead of $\mathrm{CHCl}_{3}$ is obvious, which could lead to an interesting concept for construction of a selective sensor material.

\section{Experimental Section}

\section{General}

The melting points were measured on a microscope heating stage Thermovar (ReichertJung). IR spectra were recorded on a Nicolet FT-IR 510 spectrometer as $\mathrm{KBr}$ pellets (wave numbers given in $\left.\mathrm{cm}^{-1}\right)$. ${ }^{1} \mathrm{H}$ and ${ }^{13} \mathrm{C}$ NMR spectra were obtained from a Bruker Avance 500 at $500.1\left({ }^{1} \mathrm{H}\right)$ and $125.8 \mathrm{MHz}\left({ }^{13} \mathrm{C}\right)$ using TMS as internal standard. Chemical shifts for proton and carbon resonances are given in $\operatorname{ppm}(\delta)$. Mass spectra were recorded on a Hewlett Packard 5890 Series II/MS 5971 A. Elemental analyses were measured using a Hanau vario MICRO cube. The TLC analysis was performed with aluminium sheets precoated with silica gel $60 \mathrm{~F}_{254}$ (Merck). Silica gel (63-100 $\mu \mathrm{m}$, Merck) was used for column chromatography. Starting compounds including benzo[b]thiophene (BTh) (8), bibenzyl, 4-bromotoluene, 1,4diiodobenzene, 4,4'-diiodobiphenyl, methyl 4-iodobenzoate and other reagents were purchased from commercial sources and used without further purification. Dimethyl 4,4'(ethynylene)dibenzoate (9) [19] and 4,4'-diiodotolane [39] were prepared as described in the literature. 1,3,5-Triethynylbenzene (10) has been synthesized from commercially available 1,3,5-tribromobenzene applying a Pd-catalyzed cross-coupling with MEBINOL (2-methylbut3-yn-2-ol) followed by cleavage of the 2-hydroxypropan-2-yl protection groups [20].

\section{Syntheses}

\section{Dimethyl biphenyl-4,4'-dicarboxylate (7)}

The synthesis has been carried out differing from the literature procedure [15]. A mixture of 4-(methoxycarbonyl)boronic acid (2.04 g, $11.4 \mathrm{mmol})$ and methyl 4-iodobenzoate (3.00 g, $11.4 \mathrm{mmol}$ ) in $75 \mathrm{ml}$ THF and $90 \mathrm{ml} \mathrm{H}_{2} \mathrm{O}$ was degassed (10 min) under an argon atmosphere 
followed by the addition of $\mathrm{Pd}\left(\mathrm{PPh}_{3}\right)_{2} \mathrm{Cl}_{2}(92.4 \mathrm{mg}, 0.132 \mathrm{mmol})$ and $\mathrm{NaHCO}_{3}(9.00 \mathrm{~g}, 107.1$ mmol). After refluxing for $4 \mathrm{~h}$ and cooling down to room temperature, the resulting crystalline solid was collected by vacuum filtration (fraction 1 ). The residue obtained by the evaporation of the filtrate was extracted with $200 \mathrm{ml} \mathrm{CH} \mathrm{Cl}_{2}$. Drying of the organic phase $\left(\mathrm{Na}_{2} \mathrm{SO}_{4}\right)$ and evaporation of the solvent gave a white solid (fraction 2). The two fractions were combined and crystallized from toluene to yield 7 as a white flaky solid (1.96 g, $64 \%$ ). Mp: $211-212{ }^{\circ} \mathrm{C}$ (lit. $212-213{ }^{\circ} \mathrm{C}$ [39]). ${ }^{1} \mathrm{H}$ NMR (DMSO-d 6 ): $\delta_{\mathrm{H}}=3.89\left(\mathrm{~s}, \mathrm{CH}_{3}\right), 7.91(\mathrm{~d}, \mathrm{Ar}-\mathrm{H}, J=8.55 \mathrm{~Hz}), 8.07$ $(\mathrm{d}, \mathrm{Ar}-\mathrm{H}, J=8.55 \mathrm{~Hz}) .{ }^{13} \mathrm{C}$ NMR $\left(\mathrm{DMSO}-\mathrm{d}_{6}\right): \delta_{\mathrm{C}}=52.2\left(\mathrm{CH}_{3}\right), 127.3,129.2,129.9,143.2(\mathrm{Ar}-$ C), 165.9 (COOMe).

\section{Trimethyl 3,3',3"-(benzene-1,3,5-triyl)tripropynoate (11)}

A solution of $n$-BuLi (25.8 ml, $41.2 \mathrm{mmol}, 1.6 \mathrm{M} n$-hexane) in $150 \mathrm{ml}$ dry THF was treated dropwise with 1,3,5-triethynylbenzene (10) $(2.00 \mathrm{~g}, 13.3 \mathrm{mmol})$ in $50 \mathrm{ml}$ dry THF at $-40{ }^{\circ} \mathrm{C}$ under an argon atmosphere. The temperature was decreased to $-78{ }^{\circ} \mathrm{C}$ and methyl chloroformiate $(3.2 \mathrm{ml}, 41.2 \mathrm{mmol})$ was added slowly. After stirring for $6.5 \mathrm{~h}$ at room temperature, the reaction was quenched with $1 \mathrm{M}$ hydrochloric acid $(150 \mathrm{ml})$, the mixture extracted with $\mathrm{CHCl}_{3}(150 \mathrm{ml})$, the organic phase dried $\left(\mathrm{Na}_{2} \mathrm{SO}_{4}\right)$ and the solvent evaporated. Column chromatography $\left[\mathrm{SiO}_{2} ; \mathrm{EtOAC} / n\right.$-hexane 1:6] of the crude product yielded compound 11 as a white powder $(1.27 \mathrm{~g}, 29 \%)$. Mp: $127-130{ }^{\circ} \mathrm{C} . \mathrm{R}_{\mathrm{f}}=0.44$ (EtOAc/n-hexane 1:6). ${ }^{1} \mathrm{H}$ $\operatorname{NMR}\left(\mathrm{CDCl}_{3}\right): \delta_{\mathrm{H}}=3.86\left(\mathrm{~s}, \mathrm{CH}_{3}\right), 7.80(\mathrm{~s}, \mathrm{~A}-\mathrm{H}) .{ }^{13} \mathrm{C} \mathrm{NMR}\left(\mathrm{CDCl}_{3}\right): \delta_{\mathrm{C}}=52.7\left(\mathrm{CH}_{3}\right), 81.7$, $82.0(\mathrm{C} \equiv \mathrm{C}), 121.0,137.6$ (Ar-C), 153.2 (COOMe). IR: 3070, 2954, 2226, 1716, 1584, 1430, $1354,1258,1217,1189,1153,1031,933,921,894,869,829,740,677,599,558,543,462$, 436. MS(ESI): $m / z$ calc. for $\mathrm{C}_{18} \mathrm{H}_{12} \mathrm{O}_{6}: 324.06$, found: $325[\mathrm{M}+\mathrm{H}]^{+}$. EA: calc. for $\mathrm{C}_{18} \mathrm{H}_{12} \mathrm{O}_{6}: \mathrm{C} \%$ 66.67, H\% 3.73, found: C\% 66.79, H\% 3.94.

\section{Di(benzo[b]thien-2-yl)methanone (12)}

The synthesis has been performed following the literature procedure [40] but obtaining a higher yield. To a solution of benzo[b]thiophene $(8)(8.05 \mathrm{~g}, 60 \mathrm{mmol})$ in $80 \mathrm{ml}$ dry THF at $30{ }^{\circ} \mathrm{C}$ (under argon) was added slowly $n$-BuLi (37.5 ml, 1.6M in $n$-hexane). After having stirred for $15 \mathrm{~min}$ at $-30{ }^{\circ} \mathrm{C}$, the mixture was treated with $N, N$-dimethylcarbamoyl chloride $(2.8 \mathrm{ml}, 30$ $\mathrm{mmol}$ ) and stirred again for $5 \mathrm{~h}$ at room temperature. Afterwards, the reaction mixture was cooled to $0{ }^{\circ} \mathrm{C}$, quenched with $1 \mathrm{M}$ hydrochloric acid $(120 \mathrm{ml})$ and extracted with $\mathrm{CH}_{2} \mathrm{Cl}_{2}(3 \mathrm{x}$ $120 \mathrm{ml})$. The combined organic phases were dried $\left(\mathrm{Na}_{2} \mathrm{SO}_{4}\right)$ and evaporated. The obtained crude product was stirred for $30 \mathrm{~min}$ in $70 \mathrm{ml}$ refluxing EtOH. The remaining solid was 
collected and dried to yield 2 as a white powder $(8.07 \mathrm{~g}, 91 \%)$. Mp: $162-164{ }^{\circ} \mathrm{C}$ (lit. $165.5{ }^{\circ} \mathrm{C}$ [41]). ${ }^{1} \mathrm{H}$ NMR $\left(\mathrm{CDCl}_{3}\right): \delta_{\mathrm{H}}=7.44,7.50$ (each: td, $\mathrm{BTh}_{5 / 6}, J=8.00,1.15 \mathrm{~Hz}$ ), 7.91, 7.94 (each:

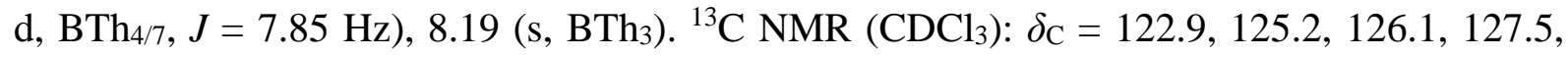
130.8, 139.0, 142.2 (BTh), $181.5(\mathrm{C}=\mathrm{O})$.

\section{1,1-Di(benzo[b]thien-2-yl)-3-(trimethylsilyl)prop-2-yne-1-ol (13)}

Under an argon atmosphere, TMSA $(1.74 \mathrm{ml}, 12.2 \mathrm{mmol})$ in $60 \mathrm{ml}$ dry THF was treated slowly at $-78{ }^{\circ} \mathrm{C}$ with $n$-BuLi $(7.6 \mathrm{ml}, 1.6 \mathrm{M} n$-hexane) followed by dropwise addition of a solution of di(benzo[b]thien-2-yl)methanone (12) $(3.00 \mathrm{~g}, 10.2 \mathrm{mmol})$ in $60 \mathrm{ml}$ dry THF. The mixture was stirred for $3 \mathrm{~h}$ at room temperature and quenched with a sat. $\mathrm{NH}_{4} \mathrm{Cl}$-solution (90 $\mathrm{ml})$. After evaporation of the solvent, the residue was extracted with $\mathrm{CH}_{2} \mathrm{Cl}_{2}$ (3x $\left.90 \mathrm{ml}\right)$. The combined organic phases were dried $\left(\mathrm{Na}_{2} \mathrm{SO}_{4}\right)$, the solvent evaporated and the obtained colourless oil stirred for $30 \mathrm{~min}$ in $40 \mathrm{ml} n$-hexane. Collection and drying of the precipitate yielded compound 13 as a white powder $(3.38 \mathrm{~g}, 85 \%)$. Mp: $145-149{ }^{\circ} \mathrm{C} .{ }^{1} \mathrm{H} \mathrm{NMR}\left(\mathrm{CDCl}_{3}\right)$ : $\delta_{\mathrm{H}}=0.28\left(\mathrm{~s}, \mathrm{SiCH}_{3}\right), 3.35(\mathrm{~s}, \mathrm{OH}), 7.31\left(2 \mathrm{td}, \mathrm{BTh}_{5 / 6}, J=7.95,7.15,1.40,1.30 \mathrm{~Hz}\right), 7.46(\mathrm{~s}$, $\left.\mathrm{BTh}_{3}\right), 7.72\left(\mathrm{~d}, \mathrm{BTh}_{4}, J=7.00 \mathrm{~Hz}\right), 7.77\left(\mathrm{~d}, \mathrm{BTh}_{7}, J=7.70 \mathrm{~Hz}\right) \cdot{ }^{13} \mathrm{C} \mathrm{NMR}\left(\mathrm{CDCl}_{3}\right): \delta_{\mathrm{C}}=0.1$ $\left(\mathrm{SiCH}_{3}\right), 70.6(\mathrm{C}-\mathrm{OH}), 93.1,105.2(\mathrm{C} \equiv \mathrm{C}), 122.4,122.7,124.4,124.7,125.0,139.3,140.5$, 149.0 (BTh). IR: 3563, 3055, 2960, 1456, 1434, 1331, 1301, 1251, 1196, 1141, 1128, 1104, 1071, 1054, 1040, 1013, 941, 835, 787, 761, 741, 726, 707, 688, 674, 628, 584, 484, 443, 437, 429. MS(ESI): $m / z$ calc. for $\mathrm{C}_{22} \mathrm{H}_{20} \mathrm{OS}_{2} \mathrm{Si}: 392.07$, found: $392[\mathrm{M}]^{+}$. EA: calc. for $\mathrm{C}_{22} \mathrm{H}_{20} \mathrm{OS}_{2} \mathrm{Si}$ : C\% 67.30, H\% 5.13, S\% 16.33, found: C\% 67.56, H\% 5.17, S\% 16.26.

\section{1,1-Di(benzo[b]thien-2-yl)prop-2-yne-1-ol (14)}

A mixture of 13 (3.00 g, $7.6 \mathrm{mmol})$ and $\mathrm{K}_{2} \mathrm{CO}_{3}(4.20 \mathrm{~g}, 30.4 \mathrm{mmol})$ in $100 \mathrm{ml} \mathrm{MeOH}$ was stirred for $7 \mathrm{~h}$ at room temperature, then diluted with $\mathrm{CH}_{2} \mathrm{Cl}_{2}(100 \mathrm{ml})$ and quenched with sat. $\mathrm{NH}_{4} \mathrm{Cl}$-solution $(100 \mathrm{ml})$. The separated aqueous phase was extracted with $\mathrm{CH}_{2} \mathrm{Cl}_{2}(100 \mathrm{ml})$ and the combined organic phases dried $\left(\mathrm{Na}_{2} \mathrm{SO}_{4}\right)$. Evaporation of the solvent gave a yellow oily residue which was stirred for $20 \mathrm{~min}$ in $25 \mathrm{ml} n$-hexane/EtOAc (10:1). The formed precipitate was collected and dried yielding 14 as a beige powder $(2.22 \mathrm{~g}, 91 \%)$. Mp: $113-116{ }^{\circ} \mathrm{C} .{ }^{1} \mathrm{H}$ NMR $\left(\mathrm{CDCl}_{3}\right): \delta_{\mathrm{H}}=3.02(\mathrm{~s}, \mathrm{C} \equiv \mathrm{CH}), 3.37(\mathrm{~s}, \mathrm{OH}), 7.33\left(2 \mathrm{td}, \mathrm{BTh}_{5 / 6}, J=7.10,7.00,1.55,1.35\right.$ $\mathrm{Hz}), 7.51\left(\mathrm{~s}, \mathrm{BTh}_{3}\right), 7.73\left(\mathrm{dd}, \mathrm{BTh}_{4}, J=7.05,1.65 \mathrm{~Hz}\right), 7.78\left(\mathrm{~d}, \mathrm{BTh}_{7}, J=7.60,1.75 \mathrm{~Hz}\right) .{ }^{13} \mathrm{C}$ NMR $\left(\mathrm{CDCl}_{3}\right): \delta_{\mathrm{C}}=70.1(\mathrm{C}-\mathrm{OH}), 75.8,84.1(\mathrm{C} \equiv \mathrm{C}), 122.4,122.5,124.2,124.5,124.9,138.9$, 140.2, 148.1 (BTh). IR: 3496, 3274, 3058, 2114, 1530, 1455, 1433, 1332, 1301, 1250, 1198 , 1147, 1098, 1059, 1014, 977, 932, 861, 836, 782, 749, 727, 709, 674, 650, 614, 593, 577, 558, 
507, 492, 428, 408. MS(ESI): $\mathrm{m} / z$ calc. for $\mathrm{C}_{19} \mathrm{H}_{12} \mathrm{OS}_{2}: 320.03$, found: $320.0[\mathrm{M}]^{+}$. EA: calc. for $\mathrm{C}_{19} \mathrm{H}_{12} \mathrm{OS}_{2}: \mathrm{C} \%$ 71.22, $\mathrm{H} \%$ 3.77, $\mathrm{S} \%$ 20.01, found: $\mathrm{C} \%$ 70.92, $\mathrm{H} \%$ 3.68, $\mathrm{S} \% 20.48$.

\section{General procedure for the synthesis of 1,3 and 6}

To a solution of benzo[b]thiophene $(8)(2.15 \mathrm{~g}, 16.0 \mathrm{mmol})$ in $20 \mathrm{ml}$ dry THF under an argon atmosphere at $-30{ }^{\circ} \mathrm{C}, n$-BuLi $(10.0 \mathrm{ml}, 16.0 \mathrm{mmol}, 1.6 \mathrm{M} n$-hexane $)$ was added slowly. The mixture was treated with the corresponding ester and stirred at room temperature. After quenching with saturated aqueous $\mathrm{NH}_{4} \mathrm{Cl}$-solution, the residue was extracted with $\mathrm{CHCl}_{3}$. The organic phase was dried $\left(\mathrm{Na}_{2} \mathrm{SO}_{4}\right)$ and the solvent evaporated. Specific details for each compound are given below.

\section{4,4'-Bis[di(benzo[b]thien-2-yl)hydroxymethyl]biphenyl (1)}

Dimethyl biphenyl-4,4'-dicarboxylate (7) (1.08 g, $4.0 \mathrm{mmol}$ ) was added as a solid in small portions and the reaction mixture was stirred for $6 \mathrm{~h}$ at room temperature. The crude product was crystallized from $\mathrm{CHCl}_{3}$ yielding compound 1 as a white solid $(2.14,72 \%)$. Mp $>284{ }^{\circ} \mathrm{C}$ (dec). ${ }^{1} \mathrm{H}$ NMR (DMSO-d 6 ): $\delta_{\mathrm{H}}=7.24$ (s, BTh 3 ), $7.33\left(2 \mathrm{td}, \mathrm{BTh}_{5 / 6}, J=7.15,1.60 \mathrm{~Hz}\right), 7.59$ (s, $\mathrm{OH}), 7.61,7.70$ (each: d, Ar-H, $J=8.55 \mathrm{~Hz}$ ), 7.80, 7.91 (each: m, BTh $4 / 7$ ). ${ }^{13} \mathrm{C}$ NMR (DMSO$\left.\mathrm{d}_{6}\right): \delta_{\mathrm{C}}=77.2(\mathrm{C}-\mathrm{OH}), 122.3,122.6,123.9,124.3,124.4(\mathrm{BTh}), 126.2,127.2,138.9$ (Ar-C), 139.0, 139.3 (BTh), 145.0 (Ar-C), 152.6 (BTh). IR: 3417, 3053, 1493, 1433, 1391, 1329, 1303, 1249, 1182, 1153, 1129, 1085, 1061, 990, 941, 894, 860, 825, 776, 744, 725, 653, 613, 567, 466, 432. $\mathrm{MS}(\mathrm{ESI}): \mathrm{m} / z$ calc. for $\mathrm{C}_{46} \mathrm{H}_{30} \mathrm{O}_{2} \mathrm{~S}_{4}: 742.11$, found: $765.2[\mathrm{M}+\mathrm{Na}]^{+}$. EA: calc. for $\mathrm{C}_{46} \mathrm{H}_{30} \mathrm{O}_{2} \mathrm{~S}_{4}: \mathrm{C} \%$ 74.36, $\mathrm{H} \%$ 4.07, S\% 17.26, found: $\mathrm{C} \%$ 74.37, $\mathrm{H} \%$ 4.13, S\% 17.56.

\section{4,4'-Bis[di(benzo[b]thien-2-yl)hydroxymethyl]tolane (3)}

Dimethyl tolane-4,4'-dicarboxylate (9) $(1.18 \mathrm{~g}, 4.0 \mathrm{mmol})$ was added as a solid in small portions and the reaction mixture was stirred for $8 \mathrm{~h}$ at room temperature. The crude product was heated for $20 \mathrm{~min}$ at $50{ }^{\circ} \mathrm{C}$ in $\mathrm{EtOH}(60 \mathrm{ml})$. Collection of the solid by filtration yielded compound 3 as a yellowish powder $(2.10,68 \%)$. Mp > $190{ }^{\circ} \mathrm{C}(\mathrm{dec}) .{ }^{1} \mathrm{H}$ NMR (DMSO-d $\left.{ }_{6}\right): \delta_{\mathrm{H}}$ $=7.20\left(\mathrm{~s}, \mathrm{BTh}_{3}\right), 7.34\left(2 \mathrm{td}, \mathrm{BTh}_{5 / 6}, J=7.10,1.70 \mathrm{~Hz}\right), 7.56,7.59$ (each: d, Ar-H, $J=8.75 \mathrm{~Hz}$ ), 7.67 (s, OH), 7.81, 7.91 (each: m, BTh $4 / 7) .{ }^{13} \mathrm{C} \mathrm{NMR}\left(\right.$ DMSO-d $\left._{6}\right): \delta_{\mathrm{C}}=77.2(\mathrm{C}-\mathrm{OH}), 89.4$ $(\mathrm{C} \equiv \mathrm{C}), 121.5$ (Ar-C), 122.3, 122.8, 124.0, 124.4, 124.5 (BTh), 127.0, 131.0 (Ar-C), 138.9, 139.3 (BTh), 146.2 (Ar-C), 152.1 (BTh). IR: 3535, 3053, 1945, 1910, 1799, 1717, 1701, 1606, 1559, 1511, 1461, 1432, 1404, 1334, 1309, 1252, 1179, 1154, 1131, 1090, 1065, 1017, 1002 , $938,891,850,815,777,748,726,710,612,587,568,463,435 . \mathrm{MS}(\mathrm{ESI}): \mathrm{m} / \mathrm{z}$ calc. for 
$\mathrm{C}_{48} \mathrm{H}_{30} \mathrm{O}_{2} \mathrm{~S}_{4}$ : 766.11, found: 749.0 [M-OH] $]^{+}$. EA: calc. for $\mathrm{C}_{48} \mathrm{H}_{30} \mathrm{O}_{2} \mathrm{~S}_{4}: \mathrm{C} \%$ 75.16, $\mathrm{H} \%$ 3.94, S\% 16.72, found: C\% 75.20, H\% 4.02, S\% 16.69.

\section{1,3,5-Tris[3,3-di(benzo[b]thien-2-yl)-3-hydroxypropynyl]benzene (6)}

Trimethyl 3,3',3"-(benzene-1,3,5-triyl)tripropynoate (11) $(0.84 \mathrm{~g}, 2.6 \mathrm{mmol})$ in $20 \mathrm{ml}$ dry THF was added dropwise and the reaction mixture was stirred for $8.5 \mathrm{~h}$ at room temperature. The crude product was heated for $15 \mathrm{~min}$ at $50^{\circ} \mathrm{C}$ in $\mathrm{EtOH}(40 \mathrm{ml})$. Collection of the solid by filtration yielded compound 6 as a yellowish brown powder $(1.45 \mathrm{~g}, 54 \%)$. Mp: $138-142{ }^{\circ} \mathrm{C}$. ${ }^{1} \mathrm{H}$ NMR $\left(\right.$ DMSO-d $\left._{6}\right): \delta_{\mathrm{H}}=7.36\left(2 \mathrm{td}, \mathrm{BTh}_{5 / 6}, J=7.20,1.30 \mathrm{~Hz}\right), 7.67(\mathrm{~s}, \mathrm{BTh} / 3), 7.87\left(\mathrm{~d}, \mathrm{BTh}_{4}\right.$, $J=7.15 \mathrm{~Hz}$ ), 7.92 (s, Ar-H), 7.93 (d, BTh,$J=7.15 \mathrm{~Hz}$ ), 8.08 (s, OH). ${ }^{13} \mathrm{C}$ NMR (DMSO-d 6 ): $\delta_{\mathrm{C}}=69.2(\mathrm{C}-\mathrm{OH}), 83.4,92.6(\mathrm{C} \equiv \mathrm{C}), 121.4,122.5$, (BTh), $123.0(\mathrm{Ar}-\mathrm{C}), 124.1,124.5,124.7$ (BTh) 134.6 (Ar-C), 138.9, 139.2, 150.2 (BTh). IR: 3441, 3057, 2227, 1625, 1583, 1529, 1458, 1434, 1417, 1332, 1307, 1251, 1187, 1128, 1104, 1056, 1015, 979, 940, 882, 861, 832, 781, 747, 726, 709, 679, 583, 438. MS(ESI): $m / z$ calc. for $\mathrm{C}_{63} \mathrm{H}_{36} \mathrm{O}_{3} \mathrm{~S}_{6}: 1032.10$, found: 1015.1 [M$\mathrm{OH}]^{+}$. EA: calc. for $\mathrm{C}_{63} \mathrm{H}_{36} \mathrm{O}_{3} \mathrm{~S}_{6} \cdot \mathrm{EtOH}: \mathrm{C} \% 72.33, \mathrm{H} \%$ 3.92, $\mathrm{S} \% 17.82$, found: $\mathrm{C} \% 71.91, \mathrm{H} \%$ $3.71, \mathrm{~S} \% 17.73$.

\section{General procedure for the synthesis of 2,4 and 5}

A mixture of 1,1-di(benzo[b]thien-2-yl)prop-2-yne-1-ol (14) (1.00 g, $3.1 \mathrm{mmol})$ and the corresponding arylhalide in $60 \mathrm{ml}$ triethylamine was degassed for $10 \mathrm{~min}$ (under argon). Then, the catalyst system containing $\mathrm{Pd}\left(\mathrm{PPh}_{3}\right)_{2} \mathrm{Cl}_{2}(21.8 \mathrm{mg}, 0.031 \mathrm{mmol}), \mathrm{CuI}(17.7 \mathrm{mg}, 0.093 \mathrm{mmol})$ and $\mathrm{PPh}_{3}(16.3 \mathrm{mg}, 0.062 \mathrm{mmol})$ was added and the subsequent reaction carried out under reflux (TLC controlled). After cooling to room temperature, the reaction mixture was diluted with $\mathrm{CHCl}_{3}(80 \mathrm{ml})$ and washed with saturated aqueous $\mathrm{NH}_{4} \mathrm{Cl}$-solution $(80 \mathrm{ml})$. The separated organic phase was dried $\left(\mathrm{Na}_{2} \mathrm{SO}_{4}\right)$ and the solvent evaporated.

\section{1,4-Bis[3,3-di(benzo[b]thien-2-yl)-3-hydroxypropynyl]benzene (2)}

The reaction was run for $7.5 \mathrm{~h}$ using 1,4-diiodobenzene $(0.49 \mathrm{~g}, 1.5 \mathrm{mmol})$ as the arylhalide. The crude product was stirred for $15 \mathrm{~min}$ in $\mathrm{EtOH} /$ acetone $(4: 1,30 \mathrm{ml})$ and the solid collected by vacuum filtration to yield compound 2 as a white powder $(1.02 \mathrm{~g}, 95 \%)$. Mp >267 ${ }^{\circ} \mathrm{C}(\mathrm{dec})$. $\mathrm{R}_{\mathrm{f}}=0.27\left(\mathrm{EtOAc} / n\right.$-hexane 1:2). ${ }^{1} \mathrm{H}$ NMR $\left(\mathrm{CDCl}_{3}\right): \delta_{\mathrm{H}}=3.92(\mathrm{~s}, \mathrm{OH}), 7.33\left(2 \mathrm{t}, \mathrm{BTh}_{5 / 6}, J=\right.$ $7.10 \mathrm{~Hz}$ ), 7.53 (s, BTh 3 ), 7.56 (s, Ar-H), 7.74, 7.79 (each: d, BTh $4 / 7, J=7.25,7.65 \mathrm{~Hz}) .{ }^{13} \mathrm{C}$ NMR $\left(\mathrm{CDCl}_{3}\right): \delta_{\mathrm{C}}=70.8(\mathrm{C}-\mathrm{OH}), 86.8,91.8(\mathrm{C} \equiv \mathrm{C}), 122.4(\mathrm{Ar}-\mathrm{C}), 122.4,122.7,124.3,124.7$, 125.0 (BTh), 132.1 (Ar-C), 139.3, 140.4, 149.0 (BTh). IR: 3523, 3050, 2872, 2233, 1500, 1455, 
$1432,1329,1303,1264,1248,1192,1123,1097,1056,1012,936,834,800,787,743,723$, 704, 676, 600, 593, 575, 548, 478, 432. MS(ESI): $\mathrm{m} / z$ calc. for $\mathrm{C}_{44} \mathrm{H}_{26} \mathrm{O}_{2} \mathrm{~S}_{4}:$ 714.08, found: $737.2[\mathrm{M}+\mathrm{Na}]^{+}$. EA: calc. for $\mathrm{C}_{44} \mathrm{H}_{26} \mathrm{O}_{2} \mathrm{~S}_{4}: \mathrm{C} \%$ 73.92, $\mathrm{H} \%$ 3.67, $\mathrm{S} \% 17.94$ found: $\mathrm{C} \% 73.72$, $\mathrm{H} \% 3.60, \mathrm{~S} \% 18.12$.

\section{4,4'-Bis[3,3-di(benzo[b]thien-2-yl)-3-hydroxypropynyl]biphenyl (4)}

The reaction was run for $8 \mathrm{~h}$ using 4,4'-diiodobiphenyl $(0.61 \mathrm{~g}, 1.5 \mathrm{mmol})$ as the arylhalide. The crude product was stirred for $10 \mathrm{~min}$ in acetone $(20 \mathrm{ml})$ and the solid collected by vacuum filtration to yield compound 4 as an orange-white powder $(0.75 \mathrm{~g}, 63 \%)$. Mp: $121-125^{\circ} \mathrm{C}$. $\mathrm{R}_{\mathrm{f}}$ $=0.20\left(\right.$ EtOAc/ $n$-hexane 1:2). ${ }^{1} \mathrm{H}$ NMR $\left(\right.$ DMSO-d $\left._{6}\right): \delta_{\mathrm{H}}=7.36\left(2 \mathrm{td}, \mathrm{BTh}_{5 / 6}, J=7.15,1.40 \mathrm{~Hz}\right)$, $7.62\left(\mathrm{~s}, \mathrm{BTh}_{3}\right.$ ), 7.73, 7.84 (each: d, Ar-H, $J=8.50 \mathrm{~Hz}$ ), 7.87, 7.93 (each: d, BTh $4 / 7, J=7.25$, $7.55 \mathrm{~Hz}), 8.03(\mathrm{~s}, \mathrm{OH}) .{ }^{13} \mathrm{C}$ NMR $\left(\mathrm{DMSO}_{-} \mathrm{d}_{6}\right): \delta_{\mathrm{C}}=69.2(\mathrm{C}-\mathrm{OH}), 85.4,91.8(\mathrm{C} \equiv \mathrm{C}), 120.9(\mathrm{Ar}-$ C), 121.2, 122.5, 124.2, 124.5, 124.7 (BTh), 127.1, 132.3 (Ar-C), 138.9, 139.2, 150.8 (BTh). IR: 3541, 3488, 3054, 2973, 2603, 2497, 2231, 1703, 1492, 1456, 1434, 1376, 1329, 1305, $1265,1249,1222,1189,1124,1109,1062,1003,944,860,837,821,804,744,725,677,630$, 582, 554, 532, 478, 428. MS(ESI): $m / z$ calc. for $\mathrm{C}_{50} \mathrm{H}_{30} \mathrm{O}_{2} \mathrm{~S}_{4}: 790.11$, found: $814.1[\mathrm{M}+\mathrm{Na}]^{+}$. EA: calc. for $\mathrm{C}_{50} \mathrm{H}_{30} \mathrm{O}_{2} \mathrm{~S}_{4}: \mathrm{C} \%$ 73.41, $\mathrm{H} \%$ 5.01, S\% 13.29 found: $\mathrm{C} \%$ 73.23, $\mathrm{H} \%$ 5.04, $\mathrm{S} \%$ 13.27 .

\section{4,4'-Bis[3,3-di(benzo[b]thien-2-yl)-3-hydroxypropynyl]tolane (5)}

The reaction was run for $8 \mathrm{~h}$ using 4,4'-diiodotolane $(0.65 \mathrm{~g}, 1.5 \mathrm{mmol})$ as the arylhalide. The crude product was heated for $20 \mathrm{~min}$ at $50{ }^{\circ} \mathrm{C}$ in EtOH/acetone $(1: 1,50 \mathrm{ml})$ and the solid collected by vacuum filtration to yield compound 5 as a beige powder $(1.17 \mathrm{~g}, 96 \%)$. Mp > $240{ }^{\circ} \mathrm{C} . \mathrm{R}_{\mathrm{f}}=0.22\left(\right.$ EtOAc/ $n$-hexane 1:2). ${ }^{1} \mathrm{H}$ NMR $\left(\right.$ DMSO-d $\left._{6}\right): \delta_{\mathrm{H}}=7.36\left(2 \mathrm{td}, \mathrm{BTh}_{5 / 6}, J=7.20\right.$, 1.30 Hz), 7.62 (s, BTh ${ }_{3}$ ), 7.67, 7.69 (each: d, Ar-H, $J=8.75$ Hz), 7.87, 7.93 (each: m, BTh4/7), $8.05(\mathrm{~s}, \mathrm{OH}) .{ }^{13} \mathrm{C}$ NMR (DMSO-d 6$): \delta_{\mathrm{C}}=69.1(\mathrm{C}-\mathrm{OH}), 85.0,90.9,92.8(\mathrm{C} \equiv \mathrm{C}), 121.2(\mathrm{BTh})$, 121.7 (Ar-C), 122.5 (BTh), 122.7 (Ar-C), 124.1, 124.5, 124.7 (BTh), 131.8, 131.9 (Ar-C), 138.9, 139.2, 150.5 (BTh). IR: 3441, 3056, 2227, 1627, 1514, 1458, 1434, 1404, 1333, 1307, 1250, 1189, 1127, 1103, 1042, 939, 860, 837, 778, 748, 725, 709, 584, 547, 436. MS(ESI): $m / z$ calc. for $\mathrm{C}_{52} \mathrm{H}_{30} \mathrm{O}_{2} \mathrm{~S}_{4}: 814.11$, found: $797.1[\mathrm{M}-\mathrm{OH}]^{+}$. EA: calc. for $\mathrm{C}_{52} \mathrm{H}_{30} \mathrm{O}_{2} \mathrm{~S}_{4}: \mathrm{C} \%$ 76.63, $\mathrm{H} \%$ 3.71, S\% 15.74 found: $\mathrm{C} \%$ 76.37, $\mathrm{H} \%$ 3.70, S\% 15.60 .

\section{Preparation of inclusion compounds}


The inclusion compounds were obtained by crystallization of 1-6, respectively, from the respective solvents. Host:guest (solvent) stoichiometric ratios were determined after careful drying ( $1 \mathrm{~h}, 15$ Torr, room temperature) of the isolated crystals via signal integration of the ${ }^{1} \mathrm{H}$ NMR spectra.

\section{$X$-ray structure determination}

Single crystals of $\mathbf{1 a}, \mathbf{2 a}, \mathbf{2 b}, \mathbf{4 a}-\mathbf{4} \mathbf{c}$ and $\mathbf{5 a}$ were grown by slow evaporation of a solution of each host in the respective solvent. The X-ray diffraction data of the studied crystals were collected at $100 \mathrm{~K}$ on a Bruker Kappa diffractometer equipped with an APEX II CCD area detector and graphite-monochromatized MoK $\alpha$ radiation $(\lambda=0.71073 \AA$ ) employing $\varphi$ and $\omega$ scan modes. The data were corrected for Lorentz and polarization effects. Semiempirical absorption correction was applied using the SADABS program [42]. The SAINT program [42] was used for the integration of the diffraction profiles. The crystal structures were solved by direct methods using SHELXS-97 [43] and refined by full-matrix least-squares refinement against $F^{2}$ using SHELXL-97 [43]. All non-hydrogen atoms were refined anisotropically. Hydrogen atoms were positioned geometrically and allowed to ride on their parent atoms. Geometrical calculations were performed using PLATON [22] and molecular graphics were generated using SHELXTL [43].

\section{Absorption measurements}

For the absorption experiments, a quartz crystal microbalance (QCM) [14] consisting of two electronic quartzes (10 MHz) with gold electrodes (FOQ Piezo Technik, Germany) was used. The reference quartz is uncoated while the other quartz is coated with the diol host. The measurements were carried out at constant temperature $\left(25^{\circ} \mathrm{C}\right)$ and with a constant flow of synthetic air $(10 \mathrm{~L} / \mathrm{h})$. A multichannel frequency counter (HKR sensor systems Munich, Germany) with a resolution of $1 \mathrm{~Hz}$ was used to measure the resonance frequencies of the quartzes which can be read by a computer using a serial interface. The coating of the quartz was realized by dipping in a $0.01 \mathrm{M}$ solution of the respective diol compound in $\mathrm{CHCl}_{3}$ (or EtOH). The change of the frequency is proportional to the increase of the quartz mass induced by the absorption of the added solvent vapor. This relation results from the Sauerbrey equation [35]. In consideration of the molar mass of the used solvents, the percentage of the absorbed solvent can be obtained as molar ratio. 


\section{Acknowledgments}

The authors thank the Ministry of Science and Art of Saxony (Cluster of Excellence “'Structure Design of Novel High-Performance Materials via Atomic Design and Defect Engineering [ADDE]',) together with the European Union (European Regional Development Fund, FK and EW) for financial support.

\section{Appendix A. Supplementary material}

Supplementary data associated with this article can be found, in the online version, at http $\mathrm{xxx}$ (to be delivered by the publisher)

CCDC-1429892 (1a), CCDC-1429893 (2a), CCDC-1429894 (2b), CCDC-1429895 (4a), CCDC-1429896 (4b), CCDC-1429897 (4c) and CCDC-1429898 (5a) contain the supplementary crystallographic data for this article. This data can be obtained free of charge at www.ccdc.cam.ac.uk/data_request/cif [or from the Cambridge Crystallographic Data Centre (CCDC), 12 Union Road, Cambridge CB2 1EZ, UK; fax: +44(0) 1223-336033; e-mail: deposit@ccdc.cam.ac.uk]. 


\section{TABLES}

\section{Table 1}

Stoichiometric ratios (host:guest) in the inclusion compounds of the new hosts $\mathbf{1}$ - $\mathbf{6}$ as well as of BTh1 and BTh2 as determined by ${ }^{1} \mathrm{H}-\mathrm{NMR}$.

\begin{tabular}{lcccccccc}
\hline Solvents & BTh1 [13] & BTh2 [13] & $\mathbf{1}$ & $\mathbf{2}$ & $\mathbf{3}$ & $\mathbf{4}$ & $\mathbf{5}$ & $\mathbf{6}$ \\
\hline $\mathrm{MeOH}$ & $1: 2$ & $c$ & - & $c$ & $c$ & $2: 5$ & $c$ & $1: 5$ \\
EtOH & $c$ & $1: 2$ & $1: 1$ & - & $c$ & $1: 2$ & $c$ & $1: 4$ \\
$n$-PrOH & $1: 2$ & - & $2: 1$ & $2: 1$ & $c$ & $c$ & $c$ & $c$ \\
$n$-BuOH & $1: 2$ & - & $2: 1$ & $1: 2$ & $1: 2$ & $1: 2$ & $c$ & $c$ \\
Diethylamine & $1: 2$ & $1: 2$ & $1: 2$ & $1: 2$ & $1: 2$ & $1: 2$ & $c$ & $c$ \\
Pyrrolidine & $1: 2$ & $1: 2$ & $1: 2$ & $1: 2$ & $c$ & $2: 5$ & $1: 2$ & $c$ \\
Acetone & $1: 2$ & $1: 2$ & $3: 2$ & $1: 2$ & $1: 1$ & $1: 1$ & $c$ & $1: 4$ \\
EtOAc & $1: 1$ & $3: 2$ & - & $c$ & $3: 4$ & $c$ & $c$ & $c$ \\
DMSO & $1: 2$ & $1: 2$ & $c$ & $c$ & $c$ & $c$ & $c$ & $1: 5$ \\
DMF & $1: 2$ & $1: 2$ & $1: 1$ & $1: 2$ & $1: 2$ & $c$ & $1: 2$ & $c$ \\
Pyridine & $1: 2$ & $1: 2$ & $1: 2$ & $1: 5$ & $1: 2$ & $1: 3$ & $1: 2$ & $1: 5$ \\
THF & $1: 2$ & $1: 2$ & $2: 3$ & $1: 2$ & $1: 2$ & $1: 4$ & $1: 2$ & $1: 5$ \\
1,4-Dioxane & $1: 2$ & $1: 2$ & $1: 4$ & $1: 5$ & $1: 3$ & $c$ & $1: 2$ & $c$ \\
Toluene & - & - & $3: 2$ & - & $1: 2$ & $2: 3$ & $c$ & $1: 2$ \\
Chloroform & - & - & - & - & - & - & - & - \\
\hline
\end{tabular}

-...solvent free, $c$...difficult to crystallize. 


\section{Table 2}

Crystallographic data and structure refinement details of the compounds studied.

\begin{tabular}{|c|c|c|c|c|c|c|c|}
\hline Compound & 1a & $\mathbf{2 a}$ & $2 b$ & $4 a$ & $4 b$ & $4 c$ & $5 \mathbf{a}$ \\
\hline Empirical formula & $\mathrm{C}_{46} \mathrm{H}_{30} \mathrm{O}_{2} \mathrm{~S}_{4} \cdot 2 \mathrm{C}_{5} \mathrm{H}_{5} \mathrm{~N}$ & $\mathrm{C}_{44} \mathrm{H}_{26} \mathrm{O}_{2} \mathrm{~S}_{4} \cdot \mathrm{C}_{5} \mathrm{H}_{5} \mathrm{~N}$ & $\mathrm{C}_{44} \mathrm{H}_{26} \mathrm{O}_{2} \mathrm{~S}_{4}$ & $\mathrm{C}_{50} \mathrm{H}_{30} \mathrm{O}_{2} \mathrm{~S}_{4} \cdot \mathrm{C}_{5} \mathrm{H}_{5} \mathrm{~N}$ & $\mathrm{C}_{50} \mathrm{H}_{30} \mathrm{O}_{2} \mathrm{~S}_{4} \cdot \mathrm{C}_{3} \mathrm{H}_{6} \mathrm{O}$ & $\mathrm{C}_{50} \mathrm{H}_{30} \mathrm{O}_{2} \mathrm{~S}_{4} \cdot 4 \mathrm{C}_{4} \mathrm{H}_{8} \mathrm{O}$ & $\mathrm{C}_{52} \mathrm{H}_{30} \mathrm{O}_{2} \mathrm{~S}_{4} \cdot 2 \mathrm{C}_{3} \mathrm{H}_{7} \mathrm{NO}$ \\
\hline Formula weight & 901.18 & 794.03 & 714.93 & 870.13 & 849.10 & 1079.44 & 961.23 \\
\hline Crystal system & Triclinic & Triclinic & Monoclinic & Triclinic & Monoclinic & Monoclinic & Triclinic \\
\hline Space group & $P-1$ & $P-1$ & $P 2_{1} / n$ & $P-1$ & $P 2_{1} / n$ & $P 2{ }_{1} / c$ & $P-1$ \\
\hline$a(\AA)$ & $8.7945(5)$ & $9.9185(3)$ & $12.6695(8)$ & $6.0208(2)$ & $15.0021(5)$ & $10.3505(3)$ & $9.9471(3)$ \\
\hline$b(\AA)$ & $10.1168(7)$ & $10.0822(3)$ & $11.4955(6)$ & $11.6678(3)$ & $17.5415(5)$ & $15.0039(4)$ & $10.1621(4)$ \\
\hline$c(\AA)$ & $13.8940(9)$ & $15.8887(5)$ & $14.9360(8)$ & $18.0972(5)$ & $17.1450(5)$ & $17.7522(5)$ & $13.6786(5)$ \\
\hline$\alpha\left(^{\circ}\right)$ & $74.758(3)$ & $105.985(2)$ & 90.0 & $88.4690(10)$ & 90.0 & 90.0 & $105.464(2)$ \\
\hline$\beta\left(^{\circ}\right)$ & $84.612(3)$ & $95.809(2)$ & $108.537(2)$ & $86.8770(10)$ & $114.801(2)$ & $90.270(2)$ & $93.123(2)$ \\
\hline$\gamma\left({ }^{\circ}\right)$ & $69.772(3)$ & $107.5240(10)$ & 90.0 & $89.5330(10)$ & 90.0 & 90.0 & $116.614(2)$ \\
\hline$V\left(\AA^{3}\right)$ & $1119.13(12)$ & $1426.87(8)$ & $2062.5(2)$ & $1268.95(6)$ & $4095.7(2)$ & $2756.85(13)$ & $1166.90(7)$ \\
\hline$Z$ & 1 & 1 & 2 & 1 & 4 & 2 & 1 \\
\hline$F(000)$ & 470 & 454 & 740 & 494 & 1768 & 1140 & 470 \\
\hline$D_{\mathrm{c}}\left(\mathrm{Mg} \mathrm{m}^{-3}\right)$ & 1.337 & 1.016 & 1.151 & 1.242 & 1.377 & 1.300 & 1.368 \\
\hline$\mu\left(\mathrm{mm}^{-1}\right)$ & 0.259 & 0.202 & 0.263 & 0.232 & 0.279 & 0.226 & 0.256 \\
\hline \multicolumn{8}{|l|}{ Data collection } \\
\hline Temperature (K) & $100(2)$ & $100(2)$ & $100(2)$ & $100(2)$ & $100(2)$ & $100(2)$ & $100(2)$ \\
\hline No. of collected reflections & 16700 & 4999 & 27517 & 22242 & 33751 & 17711 & 31295 \\
\hline within the $\theta$-limit $\left({ }^{\circ}\right)$ & $2.21-25.00$ & $2.20-25.00$ & $1.84-25.00$ & $1.75-25.00$ & $1.75-25.00$ & $2.29-25.00$ & $2.38-25.00$ \\
\hline Index ranges $\pm h, \pm k, \pm l$ & $-10 / 10,-12 / 12,-16 / 16$ & $-11 / 11,-11 / 11,0 / 18$ & $-15 / 15,-13 / 13,-17 / 17$ & $-7 / 7,-13 / 13,-21 / 21$ & $-17 / 17,-20 / 19,-20 / 20$ & $-12 / 12,-17 / 17,-20 / 21$ & $-11 / 11,-11 / 12,-16 / 16$ \\
\hline No. of unique reflections & 3943 & 4999 & 3629 & 4462 & 7188 & 4804 & 4112 \\
\hline$R_{\text {int }}$ & 0.0253 & 0 & 0.0336 & 0.0244 & 0.0262 & 0.0289 & 0.0313 \\
\hline \multicolumn{8}{|c|}{$\begin{array}{l}\text { Refinement calculations: full-matrix } \\
\text { least- squares on all } F^{2} \text { values }\end{array}$} \\
\hline Weighting expression $w^{\text {a }}$ & $\begin{array}{l}{\left[\sigma^{2}\left(F_{0}^{2}\right)+(0.0486 P)^{2}\right.} \\
+0.6253 P]^{-1}\end{array}$ & $\begin{array}{l}{\left[\sigma^{2}\left(F_{\mathrm{o}}^{2}\right)+(0.0657 P)^{2}\right.} \\
+0.5003 P]^{-1}\end{array}$ & $\begin{array}{l}{\left[\sigma^{2}\left(F_{\mathrm{o}}^{2}\right)+(0.0825 P)^{2}+\right.} \\
4.8209 P]^{-1}\end{array}$ & $\begin{array}{l}{\left[\sigma^{2}\left(F_{\mathrm{o}}^{2}\right)+(0.0514 P)^{2}\right.} \\
+1.1131 P]^{-1}\end{array}$ & $\begin{array}{l}{\left[\sigma^{2}\left(F_{\mathrm{o}}^{2}\right)+(0.0516 P)^{2}\right.} \\
+1.8524 P]^{-1}\end{array}$ & $\begin{array}{l}{\left[\sigma^{2}\left(F_{\mathrm{o}}^{2}\right)+(0.0531 P)^{2}\right.} \\
+2.1737 P]^{-1}\end{array}$ & $\begin{array}{l}{\left[\sigma^{2}\left(F_{\mathrm{o}}^{2}\right)+(0.0372 P)^{2}\right.} \\
+0.5564 P]^{-1}\end{array}$ \\
\hline No. of refined parameters & 291 & 313 & 234 & 313 & 583 & 347 & 329 \\
\hline $\begin{array}{l}\text { No. of } \mathrm{F} \text { values used }[I>2 \sigma(I)] \\
\quad \text { Final } R \text {-Indices }\end{array}$ & 3567 & 4244 & 3178 & 3951 & 5966 & 4136 & 3690 \\
\hline$R\left(=\Sigma|\Delta F| / \Sigma\left|F_{\mathrm{o}}\right|\right)$ & 0.0355 & 0.0402 & 0.0664 & 0.0449 & 0.0355 & 0.0406 & 0.0302 \\
\hline$w R$ on $F^{2}$ & 0.0938 & 0.1146 & 0.1782 & 0.1154 & 0.0937 & 0.1055 & 0.0772 \\
\hline$S$ (=Goodness of fit on $F^{2}$ ) & 1.061 & 1.097 & 1.087 & 1.061 & 1.053 & 1.045 & 1.065 \\
\hline Final $\Delta_{\max } / \Delta_{\min }\left(\mathrm{e} \AA^{-3}\right)$ & $0.441 /-0.470$ & $0.259 /-0.246$ & $0.684 /-0.434$ & $0.486 /-0.990$ & $0.447 /-0.369$ & $0.529 /-0.356$ & $0.297 /-0.321$ \\
\hline
\end{tabular}


Table 3

Selected torsion angles of the host conformations in the crystal structures of 1-6.

\begin{tabular}{cccccccc}
\hline Torsion angles (deg) & $\mathbf{1 a}$ & $\mathbf{2 a}$ & $\mathbf{2 b}$ & $\mathbf{4 a}$ & $\mathbf{4 b}$ & $\mathbf{4 c}$ & $\mathbf{5 a}$ \\
\hline$\tau 1$ (S1-C1-C17-O1) & $28.3(2)$ & $41.0(2)$ & $26.5(3)$ & $36.4(2)$ & $-58.76(2)$ & $41.1(2)$ & $-151.7(1)$ \\
$\tau 2(\mathrm{~S} 2-\mathrm{C} 9-\mathrm{C} 17-\mathrm{O} 1)$ & $43.8(2)$ & $35.9(2)$ & $-33.7(3)$ & $-37.8(2)$ & $-33.4(2)$ & $-32.8(2)$ & $-28.6(2)$ \\
\hline
\end{tabular}

\section{Table 4}

Packing properties of the crystalline inclusion compounds.

\begin{tabular}{|c|c|c|c|c|c|}
\hline & \multirow[t]{2}{*}{$\operatorname{SAV}^{\mathrm{a}}\left(\AA^{3}\right)$} & \multirow[t]{2}{*}{ Part of unit cell (\%) } & \multicolumn{2}{|c|}{$\mathrm{KPI}^{\mathrm{b}}(\%)$} & \multirow[t]{2}{*}{ Channel size $\left(\AA^{2}\right)$} \\
\hline & & & Without solvent & With solvent & \\
\hline 1a & 300.9 & 26.9 & 54.5 & 67.7 & - \\
\hline \multirow[t]{3}{*}{$2 \mathbf{a}$} & 692.0 & 48.5 & 41.2 & - & ca. $4.9 \times 6.8(a)$ \\
\hline & & & & & ca. $5.1 \times 5.5(b)$ \\
\hline & & & & & ca. $4.8 \times 6.7(c)$ \\
\hline $2 \mathbf{b}$ & 453.4 & 22.0 & 56.9 & - & ca. $5.6 \times 6.0$ \\
\hline \multirow[t]{2}{*}{$4 \mathbf{a}$} & 403.9 & 31.8 & 51.8 & - & ca. $5.8 \times 9.7(A)$ \\
\hline & & & & & ca. $6.0 \times 6.8(B)$ \\
\hline $4 b$ & 465.3 & 11.4 & 64.6 & 70.5 & - \\
\hline $4 c$ & 1027.9 & 37.3 & 47.7 & 68.6 & - \\
\hline $5 \mathbf{a}$ & 201.1 & 17.2 & 58.4 & 70.6 & - \\
\hline
\end{tabular}

\section{Table 5}

Vapor absorption ratios of the studied host compounds.

\begin{tabular}{lcccccccccc}
\hline & B Th1 $^{\mathrm{a}}[13]$ & $\mathbf{B T h 2}^{\mathrm{a}}[13]$ & $\mathbf{1}^{\mathrm{a}}$ & $\mathbf{2}^{\mathrm{a}}$ & $\mathbf{3}^{\mathrm{a}}$ & $\mathbf{4}^{\mathrm{a}}$ & $\mathbf{5}^{\mathrm{a}}$ & $\mathbf{6}^{\mathrm{a}}$ & $\mathbf{6}^{\mathrm{b}}$ & $\begin{array}{c}\text { Change of vapor } \\
\text { uptake }^{(\%)}\end{array}$ \\
\hline$n$-Hexane & 1 & 6 & 12 & 12 & 20 & 7 & 25 & 25 & 7 & -72 \\
$\mathrm{CHCl}_{3}$ & 51 & 20 & 32 & 25 & 30 & 16 & 20 & 34 & 12 & -65 \\
$\mathrm{THF}$ & 80 & 38 & 65 & 121 & 56 & 63 & 105 & 169 & 67 & -60 \\
$\mathrm{Acetone}$ & 43 & 46 & 73 & 98 & 72 & 50 & 79 & 154 & 72 & -53 \\
$\mathrm{EtOH}$ & 212 & 46 & 103 & 175 & 68 & 99 & 218 & 185 & 145 & -22 \\
$\mathrm{Et}{ }_{2} \mathrm{NH}$ & 116 & 37 & 70 & 150 & 45 & 84 & 138 & 224 & 106 & -53 \\
\hline
\end{tabular}

${ }^{\mathrm{a}}$ Deposited from $\mathrm{CHCl}_{3}$ solution. ${ }^{\mathrm{b}}$ Deposited from EtOH solution and subsequent solvent evaporation. 


\section{References}

[1] Inclusion Compounds, J. Atwood, J.E.D. Davies, D.D. MacNicol (Ed.), Oxford University Press, Oxford, U.K., 1991, vol. 4.

[2] E. Weber, in: Kirk-Othmer Encyclopedia of Chemical Technology, J.I. Kroschwitz (Ed.), Wiley, New York, $4^{\text {th }}$ edn., 1995, vol. 14, pp. 122-154.

[3] A. Nangia, in: Nanoporous Materials, G.Q. Lu, X.S Zhao (Eds.), Series on Chemical Engineering, Imperial College Press, London, 2004, vol. 4, pp. 165-187.

[4] F.H. Herbstein, Crystalline Molecular Complexes and Compounds, Oxford University Press, Oxford, U.K., 2005, vol. 1, pp. 421-513.

[5] F. Toda, in Comprehensive Supramolecular Chemistry, D.D. MacNicol, F. Toda, R. Bishop (Eds.), Elsevier, Oxford, U.K., 1996, vol. 6, pp. 465-516.

[6] D. V. Soldatov, J. Chem. Crystallogr. 36 (2006) 747.

[7] R.K.R. Jetti, F. Xue, T.C.W. Mak, A. Nangia, J. Chem. Soc., Perkin Trans. 2 (2000) 1223.

[8] Y. Diskin-Posner, G.K. Patra, I. Goldberg, J. Chem. Soc., Dalton Trans. (2001) 2775.

[9] S.A. Ikbal, S. Brahma, S.P. Rath, Inorg. Chem. 51 (2012) 9666.

[10] A. Bacchi, M Carcelli, P. Pelagatti, Crystallogr. Rev. 18 (2012) 253.

[11] P.I. Ramirez-Montes, M.E. Ochoa, R. Santillan, D. J. Ramirez, N. Farfan, Cryst. Growt Des. 14 (2014) 4681.

[12]F. Katzsch, E. Weber, CrystEngComm 17 (2015) 2737.

[13]F. Katzsch, T. Gruber, E. Weber, Cryst. Growth Des. 15 (2015) 5047.

[14] Piezoelectric Sensors, A.J.C. Steinem, A. Janshoff (Eds.), Springer-Verlag, Heidelberg, 2006.

[15] B.M. Rosen, C. Huang, V. Percec, Org. Lett. 10 (2008) 2597.

[16] P. Handa, K. Holmberg, M. Sauthier, Y. Castanet, A. Mortreux, Microporous Mesoporous Mater. 116 (2008) 424.

[17] A.-J. Tong, A. Yamauchi, T. Hayashita, Z.-Y. Zhang, B.D. Smith, N. Teramae, Anal. Chem. 73 (2001) 1530.

[18] N. Miyaura, A. Suzuki, Chem. Rev. 95 (1995) 2457.

[19] T.M. Fasina, J.C. Collings, J.M. Burke, A.S. Batsanov, R.M. Ward, D. Albesa-Jové, L. Porrés, A. Beeby, J.A.K. Howard, A.J. Scott, W. Clegg, S.W. Watt, C. Viney, T.B. Marder, J. Mater. Chem. 15 (2005) 690.

[20] A. Münch, F. Katzsch, E. Weber, F. Mertens, J. Mol. Struct. 1043 (2013) 103.

[21] K. Sonogashira, Y. Tohda, N. Hagihara, Terahedron Lett. 16 (1975) 4467. 
[22] A.L. Spek, Acta Cryst. D65 (2009) 148.

[23] A. Kucsman, I. Kapovits, M. Czugler, L. Parkanyi, A. Kalman, J. Mol. Struct. 198 (1989) 339.

[24] R. Gleiter, D.B. Werz, B.J. Rausch, Chem. Eur. J. 9 (2003) 2676.

[25]D.-L. Long, P. Kögerler, L. Cronin, Angew. Chem. Int. Ed. 43 (2004) 1817.

[26] T. Gruber, A.L. Thompson, B. Odell, P. Bombicz, C.J. Schofield, New J. Chem. 38 (2014) 5905.

[27] A.I. Kitaigorodskii, Molecular Crystals and Molecules, Academic Press, New York, 1973.

[28] G.R. Desiraju, T. Steiner, The Weak Hydrogen Bond in Chemistry and Structural Biology, IUCR Monographs on Crystallography, Oxford university Press, Oxford, U.K., 1999, vol. 9, pp. 29-121.

[29] J. Bernstein, R.E. Davis, L. Shimoni, N.-L. Chang, Angew. Chem. Int. Ed. 34 (1995) 1555.

[30] M. Nishio, Y. Umezawa, H. Suezawa, S. Tsuboyama, in: The Importance of Pi-Interactions in Crystal Engineering, E.R.T. Tiekink, J. Zukerman-Schpector (Eds.), Wiley, Chichester, 2012, pp. 1-39.

[31] M. Nishio, Y. Umezawa, K. Honda, S. Tsuboyama, H. Suezawa, CrystEngComm 11 (2009) 1757.

[32] J.J. Novoa, M.C. Rovira, C. Rovira, J. Veciana, J Tarrés, Adv. Mater. 7 (1995) 233.

[33] S.J. James, in: Encyclopedia of SupramolecularChemistry, J.L. Atwood, J.W. Steed (Eds), CRC Press, Boca Raton, FL, 2004, pp. 1093-1099.

[34] C.R. Martinez, B.L. Iverson, Chem. Sci. 3 (2012) 2191.

[35] G. Sauerbrey, Z. Phys. 155 (1959) 206.

[36]D. Eißmann, F. Katzsch, E. Weber, Tetrahedron 71 (2015) 7695.

[37] K.L. Erickson, T.E. Bostrom, R.L. Frost, Materials Lett. 59 (2005) 226.

[38]F. Wong, R.G. Buchheit, Prog. Org. Coat. 51 (2004) 91.

[39] G. Bertrand, L. Tortech, D. Fichou, M. Malacria, C. Aubert, V. Gandon, Organomet. 31 (2012) 126.

[40] V.G. Nenajdenko, E.S. Balenkova, K.Y. Chernichenko, S.S. Vshivenko, Russ. Chem. Bull. $61(2012) 1456$.

[41] W. Suh, C. Jin, Synth. Comm. 34 (2004) 4249.

[42] Bruker, SAINT, SADABS (2007) AXS Inc., Madison, Wisconsin, USA.

[43] G.M. Sheldrick, Acta Cryst. A64 (2008) 112. 